Article

\title{
Costs and Profitability of Crops for Bioeconomy in the EU
}

\author{
Calliope Panoutsou ${ }^{1, *}$ and Efthymia Alexopoulou ${ }^{2}$ \\ 1 Centre for Environmental Policy, Imperial College London, 16-18 Prince's Gardens, London SW7 1NE, UK \\ 2 CRES, Centre for Renewable Energy Sources and Saving, 19th km Marathonos Avenue, 19009 Pikermi, \\ Greece; ealex@cres.gr \\ * Correspondence: c.panoutsou@imperial.ac.uk; Tel.: +44-755-734-1846
}

Received: 23 January 2020; Accepted: 4 March 2020; Published: 6 March 2020

\begin{abstract}
The bioeconomy is the cornerstone of the EU's policy for shifting economic and societal trends towards circularity and low carbon arrangements. Europe has several crops that can be used as raw materials for this purpose, however pressure on land which might displace other activities and industrial competition for cost efficient raw materials remains a challenge. Hence, ensuring good yielding capacity and examining the likelihood to produce more by exploiting low quality, unused land can present significant opportunities to increase sustainable, locally sourced supply and at the same time offer profitable solutions to both industry and the farmers. This paper estimates the production costs of fourteen crops (oil, sugar, starch and lignocellulosic) and analyses how their profitability can be influenced by yield increases and cultivation in low quality land. Results show that there are profitable options for all crops under current market prices and land types except for cases in countries where crop productivity is rather low to sustain farm incomes. The analysis confirms that Europe has plenty crop options as raw materials for bioeconomy. Decision makers however must ensure future research and policy support are oriented towards sustainable yield increases and accelerate rehabilitation of land that is unused and of low quality.
\end{abstract}

Keywords: European crops; bioeconomy; profitability; yield increase; low quality land

\section{Introduction}

Europe has diverse domestic crop potential to supply the bio-based economy [1-4]. Current options include oil, sugar, starch and lignocellulosic crops which form the supply base for food, feed and non-food sectors [1]. Markets for the first two sectors are established and well developed while the non-food sector is emerging rapidly and aims to decrease use of petrochemicals, mitigate climate change, reduce import dependency and promote local economic development. Current economic and societal trends for greater use of renewable raw materials, combined with industrial innovation, have seen the demand for crop-based biomass increasing to include feedstocks suitable for bioenergy and biobased materials [2,3]. The role of these crops is rather prominent today as key contributors to the development of bioeconomy within the Common Agricultural Policy (CAP), [5]. Crop-based value chains are considered a very important element within the post 2020 CAP-related bioeconomy with the European Commission emphasising the need to link future national CAP Strategic plans [6] and National Bioeconomy Strategies in order to contribute significantly apart from food security to climate change, environmental protection and rural development.

The increased demand from the abovementioned policy context can present challenges by: (i) adding pressure on land which might result to displacement of other activities [7,8] and (ii) increasing competition among industries for cost efficient, sustainable raw material options [9,10]. Policy and decision makers however acknowledge [11] there are significant opportunities to exploit all crop types 
cultivated so far in Europe and contribute to GHG savings and rural development from sourcing local biomass. These can be achieved through sustainable agricultural practices that:

- Increase yields [10] with the use of varieties that are better adapted to local ecosystems, the introduction of crop rotations, the use of cover crops to prevent soil erosion in sensitive areas and at the same time increase crop production, etc.

- Enable the cultivation of crops in land that remains underutilised or unused because it is of low quality

The term 'low quality land used in this paper reflects the fact that despite its low quality the land can still be cultivated with additional input of materials. The land costs and yields presented are based on statistics and research data for low quality soil and crop systems. The authors acknowledge that there are variable (and case specific) low quality land-crop combinations which cannot be depicted by this work. The work in this paper presents estimations for national level conditions based on the economic value of land and the yield performance of the crops.

Besides being environmentally sustainable the crops should also make economic sense and be profitable options both for the farmer and the respective industries. Figures from literature suggest that raw material cost can reach up to $45 \%$ of the total bioenergy carrier or biobased material cost $[12,13]$. Therefore it is important to understand which are the production costs of crops that are currently cultivated in Europe, how these differ between average farming and low quality land, and which are the breakeven values for crop yields and market prices to ensure their economic competitiveness.

This paper evaluates the profitability of fourteen crops from the oil, sugar, starch and lignocellulosic groups under current practices and further analyses how yield increases and cultivation in low quality land could influence their economic performance. The crops are representative of European conditions and can be used as raw materials for several bioeconomy sectors. The work is structured in three sections. The first section describes the agronomic profiles and quality attributes of the selected crops and details the cost methodology. The second section presents the results for: (i) production costs at farm gate, disaggregated by Member State in EU, for two land types: average farming and low quality; (ii) profitability in these land types at current yields and market prices (using CAPRI model as baseline), [1,2] and (iii) possibilities for future improvements by either increasing crop yields or producing more feedstock in unused, low-quality land, using sustainable practices (as described in the Commission Delegated Regulation (EU) 2019/807 of 13 March 2019 [11] supplementing Directive (EU) 2018/2001). Finally, the third section discusses concluding remarks.

The work can provide quantified evidence on the production costs and opportunities to improve profitability performance of European crops as raw materials for the biobased economy. Such information can be used by research, industry and policy makers to inform decisions for the national Strategic Plans in the Common Agricultural Policy [5] and the National Bioeconomy Strategies.

Among the studied crops, cereals and oilseeds are profitable options under current market prices across EU and land types except for countries with dry arid conditions in southern Europe where yields are rather low. Sugarbeet and maize are also profitable across all the study countries and land types since their high yielding potential counterbalances their high production costs. Lignocellulosic crops present low to average profitability in all cases mostly due to low market prices. The cultivation of crops in low quality land remains case specific and requires detailed analysis since there are variations in the types and conditions which affect land marginality [12].

\section{Materials and Methods}

\subsection{Crop Characteristics}

The selected crops include annual and perennial species and are: (i) oil crops: sunflower, rapeseed and soy; (ii) sugar and starch crops: sugarbeet, wheat, barley and maize; and (iii) lignocellulosic crops: fiber sorghum, kenaf, cardoon, miscanthus, switchgrass, poplar and willow. They form a representative 
mix in terms of agronomic and climate suitability, regional distribution and quality traits for bioenergy and biobased markets. The crops' agronomic characteristics are presented in Table 1, grouped in two categories. The first includes characteristics relevant for the structure of the crop supply value chain, such as growth type, timing for establishment and harvest and yields:

- Growth type: annual crops complete their life cycle - from germination to seed production ofwithin one year. Summer annuals germinate during spring or early summer and mature by autumn of the same year. Winter annuals germinate during the autumn and mature during the spring or summer of the following year. Perennial crops grow for several years following establishment (up to 20 years for lignocellulosic grasses). They often exhibit higher productivity than annual ones and interfere less with food security since they can, to some degree, also be grown on low quality land [13-15]. The selection of annual or perennial crops in a region, or their combination, will set the framework conditions for transport, storage and delivery of raw materials to pre-processing and conversion plants. It will also determine the ways in which raw material supply can be achieved to allow year-round uninterrupted operation of plant.

- Establishment and harvest times are linked with the crop growth types and dictate the timing of supply operations.

- Crop yields prescribe the size of operations within the supply chain and determine the amount of land required. Yields are also a critical factor for the overall value chain economics and the choice of crops. However, their future increase should always consider sustainable practices. Member States towards the eastern part of Europe exhibit significantly lower yields than those of Member States with similar climate and ecology in central and western regions. Oilseed yields in Bulgaria, Hungary and Romania do not exceed 2.5 dry tonnes/ha/year while corresponding yields in France and Germany can reach more than 4 dry tonnes/ha/year. Similarly, wheat and barley do not exceed 4.5 dry tonnes/ha/year in the same countries while yields in France and Germany can reach more than 7 dry tonnes/ha/year. Comparable patterns are observed in most crops, with yields being, on average, at least $25 \%$ lower in east that in central west Europe. Hence, there are good opportunities for some European regions to deliver additional feedstock and provide additional farm income by introducing higher yielding crop varieties and improving sustainable agricultural practices.

- Within oilseed crops, rapeseed is widespread across EU Member States, while sunflower and soy have smaller geographic coverage mainly due to lower cold and frost tolerance. In the starch and sugar crops category, wheat and barley are widespread across EU Member States. Maize and sugarbeet occur also in most Member States. Lignocellulosic crops have so far been cultivated only in selected countries through research and demonstration trials with limited commercial production.

The second category of information presented in Table 1 includes the characteristics that define crop selection in a region, i.e., soil type, frost free days, salt tolerance and material input requirements. All these are crop characteristics that link to crop adaptability in certain ecosystems and ability to produce under low quality conditions. In general, perennial lignocellulosic grasses (e.g., miscanthus, switchgrass), willow and cardoon have been reported as good candidates for low quality land. Their perennial cropping patterns allow farmers to plan carefully and adjust their management techniques in such a way that nutrients can be maintained in the soils and their rooting systems can prevent topsoil erosion effects.

Table 2 describes the quality attributes, biobased products and markets of the selected crops. A mix of crops has been included in this paper to illustrate various options for cropped biomass that can be used as raw material for bioenergy, biofuels and biobased products in Europe. 
Table 1. Crop agronomic characteristics [16-30].

\begin{tabular}{|c|c|c|c|c|c|c|c|c|c|}
\hline \multirow{2}{*}{ Crop } & \multicolumn{4}{|c|}{ Structure of the Crop Supply Value Chain } & \multicolumn{5}{|l|}{ Climatic and Ecological Profile } \\
\hline & Growth Type & Establishment & Harvest & Yield (t/ha) & Soil Type/pH (min- max) & Input & Frost & ays & Salt Tolerance \\
\hline \multicolumn{10}{|l|}{ Oil crops } \\
\hline Rapeseed [21,22] & $\begin{array}{l}\text { Annual (spring), biennial } \\
\text { (winter-sown) }\end{array}$ & $\begin{array}{l}\text { Winter crops from late } \\
\text { July, spring September; }\end{array}$ & June & $1.5-4.3$ & variety of soils- well drained (6.0-7.2) & High & 130 & none & \\
\hline Sunflower [22] & Annual/rotation crop & March/April & Sept & $1-3.2$ & variety of soils- well drained (5.5-7.8) & Average & 80 & medium & \\
\hline \multicolumn{9}{|l|}{ Sugar and starch crops } & \\
\hline Sugarbeet $[16,23]$ & Annual/rotation crop & Feb/March & Sept/Nov & $50-80$ & Rich- well drained soils (6.5-7.0) & High & 90 & high & \\
\hline $\begin{array}{l}\text { Wheat }[16,23] \\
\text { Barley }[16,23]\end{array}$ & Annual/rotation crop & Oct/Nov & June & $\begin{array}{l}1.4-8 \\
3.0-8\end{array}$ & variety of soils, deep, well drained (5.5-8.0) & Average & $\begin{array}{l}100 \\
90\end{array}$ & $\begin{array}{l}\text { medium } \\
\text { high }\end{array}$ & \\
\hline Maize $[16,23]$ & Annual & & Sept/Oct & $5.5-12$ & variety of soils- well drained (5.5-7.5) & High & 90 & low & \\
\hline Fiber sorghum [22] & Annual & April/May & Sept/Oct & $15-20$ & well drained (5.5-7.5) & Average & 90 & medium & \\
\hline Kenaf $[16-18,20,22]$ & Annual & May & Sept/Oct & $10-15$ & well drained (4.6-7.5) & Average & & & \\
\hline Miscanthus $[19,24,29,30]$ & Perennial & Nov/Jan & Nov/Feb & 10 & variety of soils- well drained (4.5-8.0) & Average & 120 & & \\
\hline Switchgrass [19] & Perennial & May & Nov/Jan & $8-10$ & variety- well drained & Low & 120 & medium & \\
\hline Cardoon [26] & Perennial & Oct or Feb/Mar & Jun/July & $10-15$ & Low fertility & Low & & high & \\
\hline Poplar [27] & $\begin{array}{l}\text { Perennial; Harvested on 6-15 } \\
\text { years/(in very short rotations } \\
\text { every 2-3 years) (winter) }\end{array}$ & April & Nov/Dec & $7-28$ & Low fertility & Average & & & \\
\hline Willow [27] & $\begin{array}{l}\text { Perennial; Harvested on 3-4 } \\
\text { years rotation (winter) }\end{array}$ & April & Nov/Dec & $10-30$ & variety of soils & Average & & & \\
\hline
\end{tabular}


Table 2. Quality attributes, biobased products and markets; adapted from [31,32].

\begin{tabular}{|c|c|c|c|c|c|c|c|c|}
\hline & Crop & $\begin{array}{l}\text { Oil Content } \\
(\%)\end{array}$ & $\begin{array}{l}\text { Protein Content } \\
\text { (\% Dry Matter) }\end{array}$ & $\begin{array}{l}\text { Crude Fibre Content } \\
\text { (\% Dry Matter) }\end{array}$ & $\begin{array}{c}\text { Carbohydrates } \\
(\%)\end{array}$ & $\begin{array}{l}\text { Energy (LHV in } \\
\text { GJ/Dry Tonne) }\end{array}$ & Commodity/Product & Bioenergy and Ciobased Markets \\
\hline \multirow{7}{*}{ Oil } & \multirow[t]{2}{*}{ Rapeseed } & \multirow[t]{2}{*}{41} & \multirow[t]{2}{*}{25} & \multirow[t]{2}{*}{25} & & Oil :24 & Seed: Valued mainly for oil. & \multirow{4}{*}{$\begin{array}{l}\text { Fine chemicals, food, biofuels, } \\
\text { chemical additives } \\
\text { animal feed } \\
\text { Fine chemicals, food, biofuels, } \\
\text { chemical additives } \\
\text { Food, animal feed }\end{array}$} \\
\hline & & & & & & Straw: 15 & $\begin{array}{c}\text { Straw } \\
\text { Ced. Valued mainly }\end{array}$ & \\
\hline & Sunflower & 42 & 23 & 30 & & & $\begin{array}{l}\text { Seed: Valued mainly for oil. Minor uses include as a } \\
\text { human food and as feed for birds. }\end{array}$ & \\
\hline & & & & & & $\begin{array}{l}\text { Straw: } 15 \\
\text { Oil } 24\end{array}$ & $\begin{array}{l}\text { Straw } \\
\text { Seed: Oil }\end{array}$ & \\
\hline & Soy & 41 & 40 & 25 & & & $\begin{array}{l}\text { Soy sauce/paste: A fermented soy product from } \\
\text { soybeans, filtered and pasteurized. }\end{array}$ & $\begin{array}{l}\text { Fine chemicals, food, biofuels, } \\
\text { chemical additives, glue }\end{array}$ \\
\hline & & & & & & & $\begin{array}{l}\text { Soy curd: Obtained by precipitating proteins from } \\
\text { soy milk. }\end{array}$ & \\
\hline & & & & & & Straw: 15 & Straw & \\
\hline \multirow{3}{*}{ Starch and sugar } & Wheat & 2,5 & $11-15$ & $20-25$ & 60 & & \multirow{3}{*}{ Starch, gluten, Packaging, foam } & \multirow{3}{*}{$\begin{array}{l}\text { Food, Plastics, rubber, biofuels, } \\
\text { chemical additives, glue }\end{array}$} \\
\hline & Barley & & $12-15$ & 25 & 60 & Straw: 15 & & \\
\hline & $\begin{array}{c}\text { Maize } \\
\text { Sugarbeet }\end{array}$ & 5 & $\begin{array}{c}15 \\
5-7\end{array}$ & $\begin{array}{c}5 \\
5-7\end{array}$ & $\begin{array}{c}75 \\
65 \text { to } 70\end{array}$ & Sugar: 17.5 & & \\
\hline \multirow{7}{*}{ Lignocellulosic } & Fiber sorghum & - & 5-7 & $\begin{array}{c}5-7 \\
60\end{array}$ & $\begin{array}{l}65 \text { to } 70 \\
40\end{array}$ & $\begin{array}{l}\text { Sugar: } 17.5 \\
\quad 17\end{array}$ & \multirow{7}{*}{ Fiber, composite, packagingOil (cardoon) } & \multirow{7}{*}{$\begin{array}{l}\text { Paper, textile, building material, } \\
\text { insulation, motorcars }\end{array}$} \\
\hline & Kenaf & 20 & - & 40 & & 17 & & \\
\hline & Miscanthus & & - & 40 & 60 & 17 & & \\
\hline & Switchgrass & & - & 60 & 40 & 17 & & \\
\hline & Cardoon & $20-25$ & - & 40 & 60 & 17 & & \\
\hline & Poplar & - & - & & & 18 & & \\
\hline & Willow & - & - & & & 18 & & \\
\hline
\end{tabular}




\subsection{Model Description}

A bottom-up quantitative economic model following the principles of activity-based costing has been used (Figure 1). The model is applicable at implementation level and has well- defined system boundaries in terms of geographic scope, crop type and conversion multipliers. It can evaluate each step of the crop production chain separately, account for specificities of different regions and crops (e.g., cultivation practices, land rent, labour, etc.) and integrate both local values and statistics.

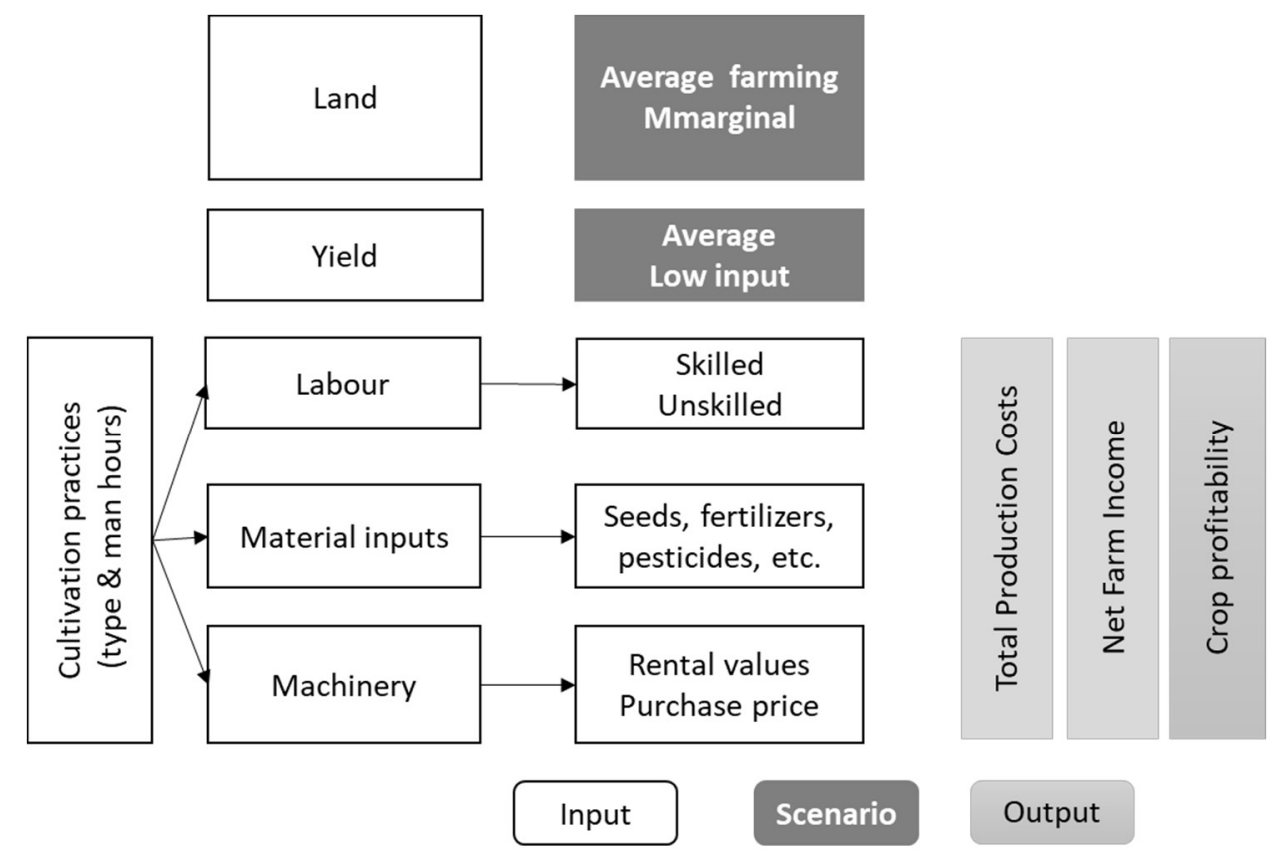

Figure 1. Cost model layout.

\subsection{Crop Selection and Data}

The selection of crops was based on a multi-criteria analysis (including their presence in European agriculture, knowledge for their cultivation in low quality land/low input systems, data availability for their yielding capacities in the countries they are cultivated and suitability as raw materials for bioenergy, biofuels and biobased materials).

Data were sourced from literature and through consultation with experts, within the framework of the four European research projects during the period 2009-2017 (Crops2Industry, Biomass Futures, Biomass Policies and S2Biom). The data are disaggregated at country level for the European Union. Values have also been cross checked with current statistics to preserve the validity of the estimated outputs.

\subsection{Cost Analyses}

This section provides the methodology for the assessment of Total Production Costs (TPC), Net Farm Profit (NFP) and crop profitability. It is important to note that all values are calculated without subsidies to avoid including market distortion created by policy interventions.

For the analyses presented in this paper, costing was based on time effort (man hours per hectare) required for each step of the production chain (Table 3).

Time required has then been costed using labour values from national and European statistics [33, 34], assuming 70\% unskilled and 30\% skilled labour. Reference year for labour statistics was 2017. The values are in Table A2 in the Appendix A.

Following, the cost layout used the Discounted Cash Flow approach, by breaking total cost by production factor. The following factors have been analysed: 
Table 3. Average time (in man hours/ha) required to perform the operations for the cultivation practices involved in the production of each crop.

\begin{tabular}{|c|c|c|c|c|c|c|c|c|c|}
\hline & Ploughing & Harrowing & Herbicide Application & Initial Fertilising & Sowing/Planting & Irrigation & Fertilising & Harvesting & Hours/ha \\
\hline Rapeseed & 1.5 & 0.7 & 0.5 & 0.5 & 1 & 0 & 0.5 & 1.5 & 6.2 \\
\hline Sunflower & 1.5 & 0.5 & 1 & 0.7 & 1 & 0 & 1 & 1.5 & 7.2 \\
\hline Soy & 1.5 & 0.7 & 0.5 & 0.5 & 1 & 0 & 0.5 & 1.5 & 6.2 \\
\hline Sugarbeet & 2 & 0.5 & 1 & 1 & 2 & 2 & 1 & 3 & 12.5 \\
\hline Wheat & 1.5 & 0.7 & 0.5 & 0.5 & 1 & 0 & 0.5 & 1.5 & 6.2 \\
\hline Barley & 1.5 & 0.7 & 0.5 & 0.5 & 1 & 0 & 0.5 & 1.5 & 6.2 \\
\hline Maize & 1.5 & 0.5 & 1 & 1.5 & 1 & 3.5 & 1 & 2 & 12 \\
\hline Fiber sorghum & 1.5 & 0.5 & 1 & 1.5 & 1 & 3.5 & 1 & 3 & 13 \\
\hline Kenaf & 1.5 & 0.5 & 1 & 1 & 1 & 2 & 1 & 2 & 10 \\
\hline Miscanthus & 2 & 1 & 1 & 1 & 2 & 2 & 1 & 3 & 13 \\
\hline Switchgrass & 1.5 & 1 & 1 & 1 & 1 & 2 & 1 & 3 & 11.5 \\
\hline Cardoon & 1.5 & 1 & 1 & 1 & 1 & 2 & 1 & 3 & 11.5 \\
\hline Poplar & 1.5 & 1 & 1 & 1 & 2 & 2 & 1 & 4.5 & 14 \\
\hline Willow & 1.5 & 1 & 1 & 1 & 2 & 2 & 1 & 4.5 & 14 \\
\hline
\end{tabular}


Labour (skilled and unskilled): Labour required for each crop production stage (establishment, annual management, etc.) and cultivation practice has been calculated. For each country average wage values in the agricultural sector were used.

Land: it has been estimated as the opportunity cost of land based on current activity (fallow land, cereals cultivation, unused, etc.). This cost is usually determined by soil productivity combined with economic forces that affect demand for land resources in the region. In this paper analyses have been performed for three land types: (i) high productivity, (ii) average farming and (iii) low quality.

Machinery: rent of tractor, harvester and travelling gun has been added to the cost analyses.

Material Inputs: seeds, fertilizers, pesticides, etc., which are usually expenses paid by the farmer to the local market. Therefore, these cost items enter the calculations at average country market prices. Energy in the form of fuel, electricity, etc., has also been included.

Total production costs (TPCs) have been estimated by summing the expenses listed above and an allowance for depreciation of fixed assets including buildings and equipment. For perennials, all expenses involved in these cost production factors are transformed into annual equivalent values at an appropriate interest rate, as follows:

$$
e=c i /\left[1-(1+i)^{n}\right]
$$

where $e=$ annual equivalent $\operatorname{cost}, c=$ purchase cost, $i=$ interest rate, and $n=$ lifespan. This value is equivalent to depreciation plus interest on capital employed. Following, the annual equivalent is added to the recurring costs to estimate the total annual equivalent cost.

All the costs used are market prices excluding subsidies and taxes. Current prices are used, and a depreciation allowance is included to account for the portion of long-term capital investment used in the year being considered [35,36]. The scenarios outlined in Table 4 have been analysed for each crop and country.

Table 4. Assumptions for the study scenarios.

\begin{tabular}{|c|c|c|c|c|}
\hline $\begin{array}{c}\text { Land } \\
\text { (Table A1 in Appendix A } \\
\text { Per Country) }\end{array}$ & Yield & $\begin{array}{c}\text { Labour } \\
\text { (Table A2 in Appendix A } \\
\text { Per Country) }\end{array}$ & Material Inputs & $\begin{array}{c}\text { Displaced Cropping } \\
\text { Activity (for Comparisons } \\
\text { in this Paper) }\end{array}$ \\
\hline Average farming & $\begin{array}{l}\text { Average yields reported by } \\
\text { statistics or research (see } \\
\text { Table A3 with country } \\
\text { values in Appendix A) }\end{array}$ & $\begin{array}{l}70 \% \text { skilled } \\
30 \% \text { unskilled }\end{array}$ & $\begin{array}{l}\text { Estimated costs for material } \\
\text { inputs per crop are provided } \\
\text { in Tables A4 and A6 in the } \\
\text { Appendix A }\end{array}$ & Cereals \\
\hline Low quality & $\begin{array}{l}30 \% \text { reduction in the } \\
\text { average yields }\end{array}$ & $\begin{array}{l}70 \% \text { skilled } \\
30 \% \text { unskilled }\end{array}$ & $\begin{array}{l}20 \% \text { higher than the average } \\
\text { scenario }\end{array}$ & No activity \\
\hline
\end{tabular}

Average yields reported by statistics or research (see Table A3 with country values in )

\subsection{Net Farm Profit and Crop Profitability}

The calculation of net farm profit (NFP) is based on the following equation:

$$
N F P=G I-T P C
$$

where: NFP: net farm profit, GI: Gross income is estimated as the revenue resulting from multiplying the produced quantity by current market prices (see Table A5 in Appendix A per country). In this paper, average crop yields and market selling prices per EU Member State have been collected from EUROSTAT, cross checked with national statistics and validated by stakeholders and TPC: Total Production Costs

The analysis provides an estimate of the return to capital invested and to the farmer's labour, and this may then be compared with the return to alternative cropping patterns or to off-farm opportunities [37]. 
The profitability of the crops has also been estimated by using a profitability index:

$$
P I=\text { Gross sales income } / \text { Total Production Costs } .
$$

The crop is considered a profitable option when PI $\geq 1$. Net farm profit and crop profitability are not the same. When analysing farm profitability, you consider the relationship of net farm profit to the land, labour and material input invested to produce a specific crop. With crop profitability, it is easier to compare various crop options for a given farm and analyse how they perform under various market prices.

\section{Results}

\subsection{Total Production Costs}

This section presents total crop production costs (TPC) at farm gate and discusses variations between crops and countries.

Values for oil crops (rapeseed, sunflower, soy) and cereals (wheat, barley) are within similar ranges within a given country, since the crops are annual species with comparable cultivation practices. Observed variations among the countries can be attributed to land rent values, cost of seeds and other material inputs (like pesticides, etc.) which are required throughout the cultivation and correspond to the crops' biophysical tolerance to diseases, insects and adaptation to prevailing climate. Among oilseeds sunflower and soybeans require less intensive crop management than rapeseed and their respective costs are slighltly lower in most countries (http://www.agribenchmark.org/agri-benchmark/ news-and-results/einzelansicht/artikel//rapeseed-su.html). All data are provided in Tables A7 and A8 in the Appendix A.

Total production costs (TPC) for the oilseeds and cereals under study vary from 250 to $1290 € /$ ha/year across EU countries, depending on the land type. Countries with low values (250-500 $€$ /ha/year) across the two land types are Bulgaria, Czech Republic, Estonia, Finland, Croatia, Hungary, Latvia, Lithuania, Luxemburg, Romania, Slovakia and Slovenia. Austria, France, Germany, Greece, Ireland, Poland and United Kingdom are countries with average values (500-750 €/ha/year). Countries with high values (750-1000 $€ /$ ha/year) are Belgium, Denmark, Spain, Italy and Sweden while the Netherlands exhibit values higher than $1000 € /$ ha/year when the crop is cultivated in average farming land. This is attributed to high land rent costs. These values are in line with literature [38,39].

Sugar beet and maize exhibit higher TPC, ranging from 450 to $1200 € /$ ha/year. Countries with values from $450-750 € /$ ha/year, across the two land types, are Bulgaria, Croatia, Hungary, Latvia, Luxemburg, Romania and Slovakia. Austria, Finland, Greece, Poland, Portugal, Spain and United Kingdom have values ranging from 750 to $1000 € /$ ha/year. Countries with values above $1000 € /$ ha/year are Denmark, France, Germany, Italy, Netherlands and Sweden. The high costs are also attributed to high land rental values.

Within lignocellulosic crops, the annual species of kenaf and fiber sorghum have TPC ranging from 280 to $700 € /$ ha/year. These two crops are cultivated with seeds and are resistant to diseases and insects thus require low materials input. Annualised costs for the other five perennial lignocellulosic crops, i.e., cardoon, switchgrass, miscanthus, willow and poplar have cost values ranging from 130 to $1100 € /$ ha/year approximately. The low ranges of costs refer to cardoon [40] and switchgrass which are cultivated with seeds thus their establishment is of low cost. Miscanthus, willow and poplar exhibit higher establishment costs due to purchasing and planting rhizomes and plantings as well as harvesting. Similar results can be found in the literature [41-43].

For kenaf and fiber sorghum countries with values from 280 to $500 € /$ ha/year are Austria, Bulgaria, Croatia, Czech Republic, Greece, Hungary, Ireland, Latvia, Poland, Portugal, Slovakia, Slovenia, Romania and UK. For switchgrass countries with values from 130 to $250 € /$ ha/year are Austria, Bulgaria, Croatia, Czech Republic, Estonia, Greece, Hungary, Ireland, Latvia, Lithuania, Poland, Portugal, Slovakia, Slovenia, Romania and UK. For miscanthus countries with values 145-250 €/ha/year are 
Bulgaria, Croatia, Czech Republic, Estonia, Greece, Hungary, Ireland, Latvia, Lithuania, Slovakia, Slovenia, Romania and UK. Similar values have been estimated by other researchers as well [44]. Finally countries with values below $500 € /$ ha/year for willow and poplar are Bulgaria, Croatia, Czech Republic, Estonia, Hungary, Latvia, Lithuania, Slovakia, Slovenia and Romania. The variations observed are confirmed by literature [45,46] and are due to land and labour costs as well as differences in propagation and harvest costs [47]. Detailed data for the Total Production Costs per crop, country and land type can be found in Appendix A.

Table 5 complements Figure 2. It provides crop costs per land unit and per tonne and indicates the share of land rent to the Total Production Costs. Figure 3 expresses the costs presented in Table 5 and Figure 2 as total crop production costs in $€$ /tonne in order to illustrate the effect of crop yields. Median yield values are used for each crop.

Table 5. Crop total production costs in $€ /$ ha and $€ / t$, averaged over countries (in bold, grey highlight those costs that are above current market prices).

\begin{tabular}{|c|c|c|c|c|c|c|}
\hline \multirow{2}{*}{ Crop } & \multicolumn{6}{|c|}{ Total Production Costs (Average Over Countries) Per ha and Per Tonne } \\
\hline & TPC (€/ha) & TPC $(€ / t)$ & Land Cost Share $(\%)$ & TPC (€/ha) & $\operatorname{TPC}(€ / t)$ & Land Cost Share $(\%)$ \\
\hline Rapeseed & 430 & 287 & 45 & 482 & 161 & 37 \\
\hline Sunflower & 376 & 376 & 51 & 455 & 228 & 39 \\
\hline Soya & 391 & 261 & 49 & 467 & 187 & 38 \\
\hline Barley & 442 & 147 & 44 & 486 & 97 & 37 \\
\hline Maize & 658 & 132 & 29 & 690 & 99 & 26 \\
\hline Fiber sorghum & 400 & 50 & 49 & 482 & 32 & 37 \\
\hline Kenaf & 417 & 52 & 46 & 499 & 35 & 36 \\
\hline Miscanthus & 531 & 48 & 50 & 392 & 39 & 46 \\
\hline Switchgrass & 511 & 33 & 84 & 332 & 37 & 54 \\
\hline
\end{tabular}

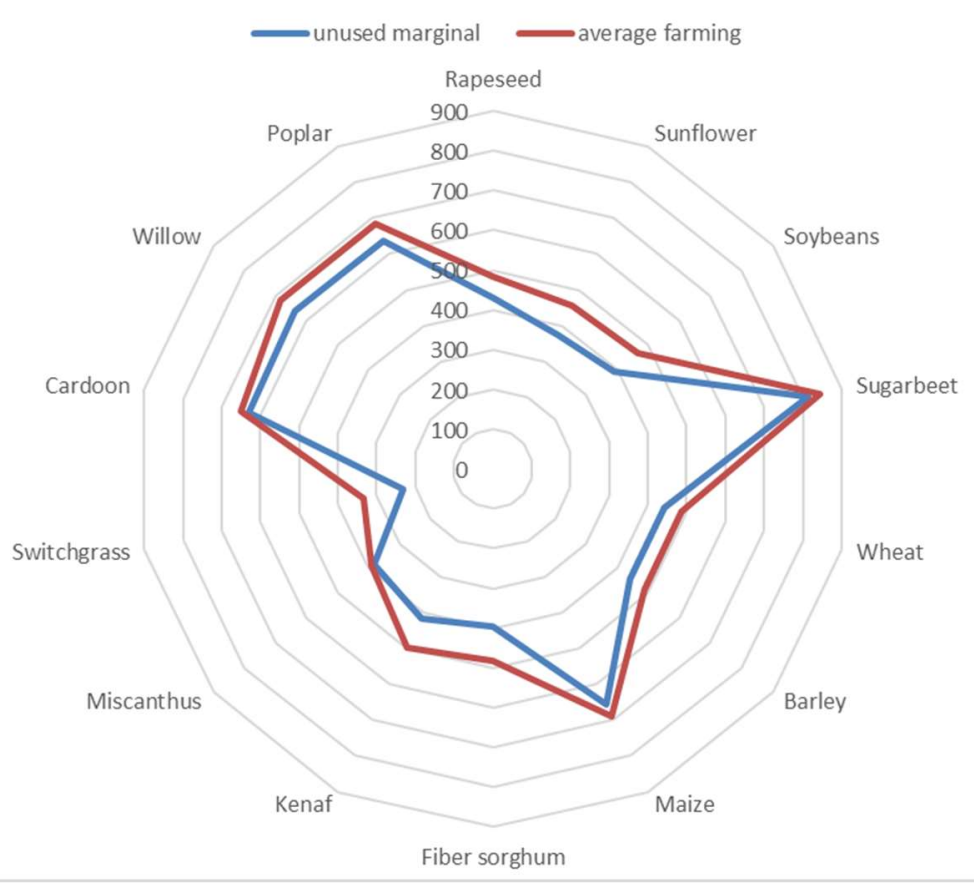

Figure 2. Total crop production costs (TPC) $(€ /$ ha/year) averaged over the countries under study in average farming and low quality land types. 


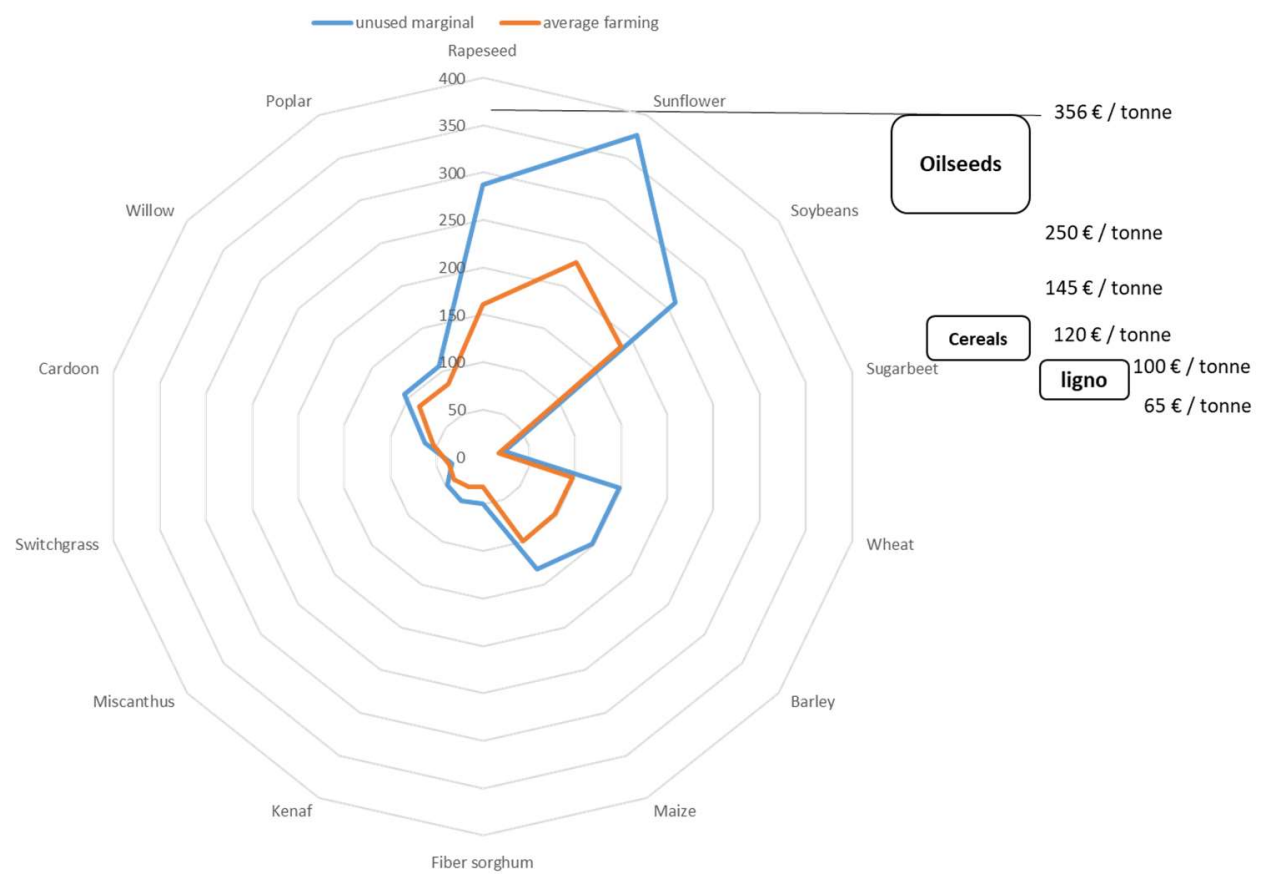

Figure 3. Total crop production costs (TPC) (€/tonne) averaged over EU Member States in average farming and low quality land types. Ranges for market selling prices during the last decade are displayed on the right part of the graph.

Although sugarbeet is an input- intensive crop with high production costs per land unit, these are offset by its high yields. The crop's cost per tonne is considerably smaller (10-23€/tonne) than cereals (62-147€/tonne) and oil crops (112-376€/tonne). Respective values for maize range from 71 to $132 € /$ tonne.

It is notable that market selling prices for oilseeds in EU are at their highest levels, at the time of writing this paper. During the last decade, they have ranged from 250 to $350 € /$ tonne. If the selling price drops to its ten-year low then the production of rapeseed, sunflower and soybeans in low quality land would become uneconomic.

The situation is similar for cereals where prices ranged from 120 to $150 € /$ tonne. If selling prices drop to the lower levels in the last ten years, the cultivation of these crops in low quality land would also become uneconomic.

Among lignocellulosic crops, cost values for fiber sorghum, kenaf and cardoon range from 38 to $63 € /$ tonne while for the rest of the crops they range from 39 to $106 € /$ tonne. This differentiation reflects mainly the higher establishment costs for the second group [48,49], both in terms of purchase of propagation material (rhizomes, cuttings, etc.) $[50,51]$ and in labour requirements. The market for lignocellulosic crops is in its infancy so it is difficult to predict selling prices [52]. In the paper values from 65 to $90 € /$ tonne are considered [53,54]. They correspond to $4-5.5 € / G J$ and has been reported in previous research as acceptable by the industry [55].

Overall, results presented in Table 5 indicate that although crop Total Production Costs for low quality land are lower than those of average farming land, the respective yields are also much lower so crop production costs per tonne are higher. This is prominent in the case of oil crops and cereals where the Total Production Costs per land unit in low quality land are slightly lower (approximately $50 € /$ ha) than in average farming but the crop cost per tonne is significantly higher ranging from 287 (low quality) to $161 € /$ tonne (average farming) for rapeseed, from 376 to $228 € /$ tonne for sunflower, from 261 to $187 € /$ tonne for soy, from 147 to $97 € /$ tonne for wheat and barley.

Sugarbeet also exhibits a small difference in the Total Production Costs for the two land types while the cost per tonne is reduced in the average farming land ( $17 € /$ tonne) when compared to low quality ( $23 € /$ tonne). 
In the lignocellulosic crops, differences in Total Production Costs per land unit are mostly proportionate to the ones per tonne of produced biomass in all the crops under study except willow and poplar which display significant reduction of production costs per tonne in the average farming land [56,57] (from 106 to 85€/tonne).

\subsection{Net Farm Profit and Crop Profitability}

This section analyses net farm profit and crop profitability for the selected crops.

\subsubsection{Net Farm Profit (NFP)}

Net farm profit represents the annual profit a farmer can make from selling his/her crop after total production costs are deducted. It is related to both yields and market selling prices. Figure 4 below presents the average net farm profits for the two land types. Table 6 also presents the crop profitability performance per country and clusters them in three groups, i.e., (i) countries with PI $\leq 1$, (ii) with PI from 1 to 2 and (iii) with PI $\geq 2$.

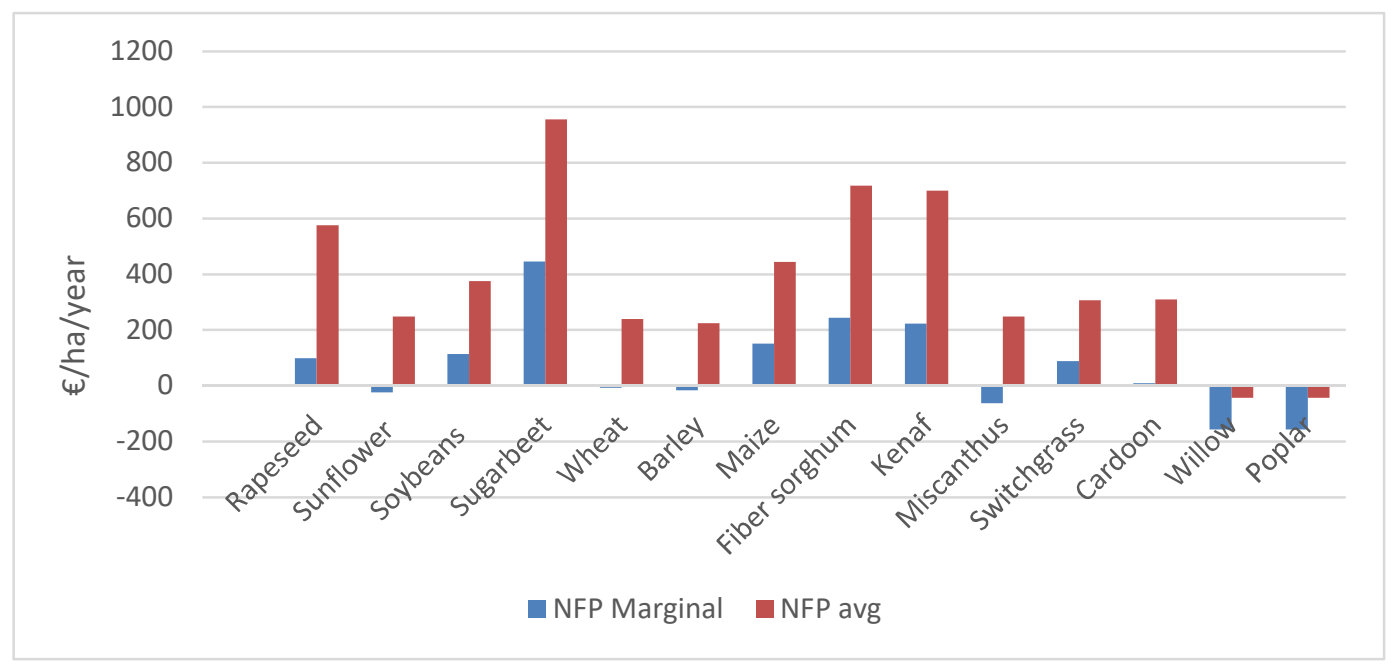

Figure 4. Net farm profit ( $€ /$ ha/year) per crop averaged over all countries and with median market prices (2018) per crop.

The values reflect the net farm profit for each crop and land type and are calculated without subsidies to avoid including market distortion caused by policy interventions. All values are presented in Tables A9 and A10 in Appendix A per country.

Table 6 below provides detailed values for the net farm profit (NFP) and profitability index (PI) for low quality and average farming land for all crops averaged for the European countries.

For average farming land, all crops except willow and poplar have net margins that are higher than cereals in the same region [58]. The situation is quite different for low quality land. Sunflower, wheat, barley, miscanthus, willow and poplar are uneconomic while the rest exhibit low margins. The only exceptions, under current market selling prices, are maize, fiber sorghum, kenaf and sugarbeet.

Based on the analysis in this paper, sunflower needs a $7 \%$ yield increase to become profitable in low quality land. The respective values for wheat, barley are $2 \%$ and $4 \%$. Miscanthus would require a $20 \%$ yield increase while willow and poplar would require 30\% yield increase. Yields for each crop and country are presented in Table A3 in the Appendix A. All crops present profits in average farming land. These figures are of course highly dependent on yields and land costs in individual cases. 
Table 6. Net Farm Profit (NFP) and profitability index (PI) for low quality and average farming land (in bold those with negative margins and profitability). Costs in the last three columns column have been estimated using country market prices and crop yields.

\begin{tabular}{|c|c|c|c|c|c|c|c|c|c|c|}
\hline \multirow{3}{*}{ Crop } & \multicolumn{6}{|c|}{$\begin{array}{l}\text { Net Farm Profit (NFP) and Profitability Index (PI) (Median Average Over Countries) } \\
\text { Per Hectare and Per Tonne }\end{array}$} & \multirow[t]{3}{*}{$\begin{array}{c}\text { Average Market } \\
\text { Selling Prices } \\
(€ / t)\end{array}$} & \multirow[t]{3}{*}{$\begin{array}{c}\text { Countries } \\
\text { with PI } \leq 1 \text { in Average } \\
\text { Farming Land } \\
\end{array}$} & \multirow[t]{3}{*}{$\begin{array}{c}\text { Countries } \\
\text { with PI: 1-2 in Average } \\
\text { Farming Land } \\
\end{array}$} & \multirow[t]{3}{*}{$\begin{array}{c}\text { Countries } \\
\text { with PI } \geq 2 \text { in Average } \\
\text { Farming Land } \\
\end{array}$} \\
\hline & \multicolumn{3}{|c|}{ Low Quality Land } & \multicolumn{3}{|c|}{ Average Farming Land } & & & & \\
\hline & NFP ( $($ /ha) & NFP ( $(\varepsilon / t)$ & PI & NFP (E/ha) & $\operatorname{NFP}(\boldsymbol{\epsilon} / \mathrm{t})$ & PI & & & & \\
\hline Rapeseed & 99 & 66 & 1.23 & 577 & 192 & 2.20 & 353 & $\mathrm{I}, \mathrm{GR}, \mathrm{NL}$ & DK, FIN, FR, ES, PL, RO, S & $\begin{array}{c}\text { AU, BE, BG, CZ, EST, DE, HR, } \\
\text { HUN, }\end{array}$ \\
\hline Sunflower & -24 & -24 & 0.94 & 261 & 131 & 1.59 & 352 & I, ES, PT & $\mathrm{FR}, \mathrm{DE}, \mathrm{GR}, \mathrm{PL}$ & $\mathrm{AU}, \mathrm{CZ}, \mathrm{HR}, \mathrm{HUN}, \mathrm{RO}, \mathrm{SK}, \mathrm{SI}$ \\
\hline Soya & 115 & 77 & 1.29 & 393 & 157 & 1.87 & 337 & GR, PL & $\mathrm{BG}, \mathrm{FR}, \mathrm{DE}, \mathrm{I}, \mathrm{SK}$ & $\mathrm{AU}, \mathrm{ES}, \mathrm{HR}, \mathrm{HUN}, \mathrm{RO}$ \\
\hline Sugarbeet & 446 & 13 & 1.55 & 999 & 20 & 2.25 & 36 & - & DK, HUN, PT & $\begin{array}{l}\mathrm{AU}, \mathrm{BE}, \mathrm{CZ}, \mathrm{ES}, \mathrm{FR}, \mathrm{GR}, \mathrm{HR}, \mathrm{I}, \mathrm{LT}, \\
\mathrm{NL}, \mathrm{PL}, \mathrm{RO}, \mathrm{SK}, \mathrm{UK}\end{array}$ \\
\hline Wheat & -7 & -2 & 0.98 & 239 & 48 & 1.49 & 145 & $\mathrm{CY}, \mathrm{PT}$ & $\begin{array}{c}\text { BE, BG, CZ, ES, EST, FIN, } \\
\text { HUN, FR, GR, I, LV, LT, NL, PL, } \\
\text { RO, RS, S }\end{array}$ & $\begin{array}{c}\mathrm{AU}, \mathrm{DE}, \mathrm{HR}, \mathrm{HUN}, \mathrm{IRL}, \mathrm{LUX} \\
\text { MLT, SK, UK }\end{array}$ \\
\hline Barley & -16 & -5 & 0.96 & 224 & 45 & 1.46 & 142 & $\mathrm{CY}, \mathrm{ES}, \mathrm{GR}, \mathrm{I}, \mathrm{PL}, \mathrm{PT}, \mathrm{S}$ & $\begin{array}{l}\text { BE, BG, CZ, ES, EST, FIN, } \\
\text { HUN, FR, DE, HR, IRL, LT, } \\
\text { LUX, MLT, NL, RO, SK, SI }\end{array}$ & $\mathrm{AU}, \mathrm{HUN}, \mathrm{UK}$ \\
\hline Maize & 152 & 30 & 1.23 & 452 & 65 & 1.66 & 162 & - & $\begin{array}{l}\text { AU, BE, BG, CZ, DE, FR, HR, } \\
\text { HUN, I, NL, PL, PT, SK, SI }\end{array}$ & ES, GR, LT, LUX, RO \\
\hline $\begin{array}{l}\text { Fiber sorghum } \\
\text { Kenaf }\end{array}$ & $\begin{array}{l}244 \\
223\end{array}$ & $\begin{array}{l}30 \\
28\end{array}$ & $\begin{array}{l}1.62 \\
1.54\end{array}$ & $\begin{array}{l}718 \\
701\end{array}$ & $\begin{array}{l}48 \\
47\end{array}$ & $\begin{array}{l}2.49 \\
2.40\end{array}$ & $\begin{array}{l}80 \\
80\end{array}$ & - & $\mathrm{ES}, \mathrm{FR}, \mathrm{DE}, \mathrm{GR}, \mathrm{HR}, \mathrm{HUN}, \mathrm{I}$ & BG, CY, HR, HUN, PL, PT, RO \\
\hline Miscanthus & -63 & -16 & 0.84 & 248 & 31 & 1.63 & 80 & - & $\mathrm{DK}, \mathrm{FR}, \mathrm{DE}, \mathrm{I}, \mathrm{NL}, \mathrm{S}$ & $\begin{array}{l}\mathrm{BG}, \mathrm{CY}, \mathrm{CZ}, \mathrm{GR}, \mathrm{HR}, \mathrm{HUN}, \mathrm{PL}, \mathrm{PT} \text {, }\end{array}$ \\
\hline Switchgrass & 89 & 22 & 1.39 & 308 & 38 & 1.92 & 80 & & & \\
\hline Cardoon & 9 & 1 & 1.01 & 228 & 19 & 1.31 & 80 & & CY, ES, FR, GR, I, PT & BG, HR, HUN, RO, UA \\
\hline $\begin{array}{l}\text { Poplar } \\
\text { Willow }\end{array}$ & $\begin{array}{l}-156 \\
-156\end{array}$ & -26 & 0.75 & -42 & -5 & 0.94 & 80 & & ES, FR, DE, GR, HR, HUN, I & BG, CY, HR, HUN, PL, PT, RO \\
\hline Willow & -156 & -26 & 0.75 & -42 & -5 & 0.94 & 80 & & & \\
\hline
\end{tabular}




\subsubsection{Crop profitability}

Crop profitability allows farmers to compare several crop options for a given farm and analyse how they perform under prevailing market prices. The sections below examine the effect of current yields and market prices on the crops under study and discusses what improvements are required to make them profitable options for farmers. All values are presented in Tables A11 and A12 in Appendix A per country.

Yields: This section estimates baseline yields required for each crop to be profitable and discusses how these relate to the crops and countries. The analysis considers as breakeven point for a crop to become profitable all values above one - where Gross Sales Income becomes equal to Total Production Costs (or Profitability Index =1).

Average yields for cereals in EU range from 2.5 to $8.0 \mathrm{t} /$ ha/year. Yield levels, above which the crops are profitable under current market selling prices are estimated at 3-3.5 t/ha/year depending on the land type. This suggests these crops are currently profitable in all countries except Cyprus, Spain, Greece and Portugal in low quality land types.

Average yields for oilseeds in EU range from $1.5 \mathrm{t} / \mathrm{ha}$ /year (soy, sunflower) to $8 \mathrm{t} / \mathrm{ha} /$ year (rapeseed). Yield levels, above which the crops are profitable under current market selling prices are estimated at 1-1.4 $\mathrm{t} / \mathrm{ha} /$ year depending on the land type. Hence, oilseeds are currently profitable crops for all EU countries. Sugarbeet is profitable throughout EU under current prices; the required baseline is 2.6-2.8 $\mathrm{t} / \mathrm{ha}$ /year while average yield in all countries is significantly higher, ranging from $25-80 \mathrm{t} / \mathrm{ha} /$ year. The situation is similar for maize which requires baseline yields of $4-4.4 \mathrm{t} / \mathrm{ha} / \mathrm{year}$, while the average yield range is 5- $12 \mathrm{t} / \mathrm{ha}$ /year. Finally, baseline yields for lignocellulosic crops range from 5.5 to $6.3 \mathrm{t} / \mathrm{ha} / \mathrm{year}$. These are profitable in all countries except for willow and poplar which are not profitable on low quality land in several countries (Figure 5).

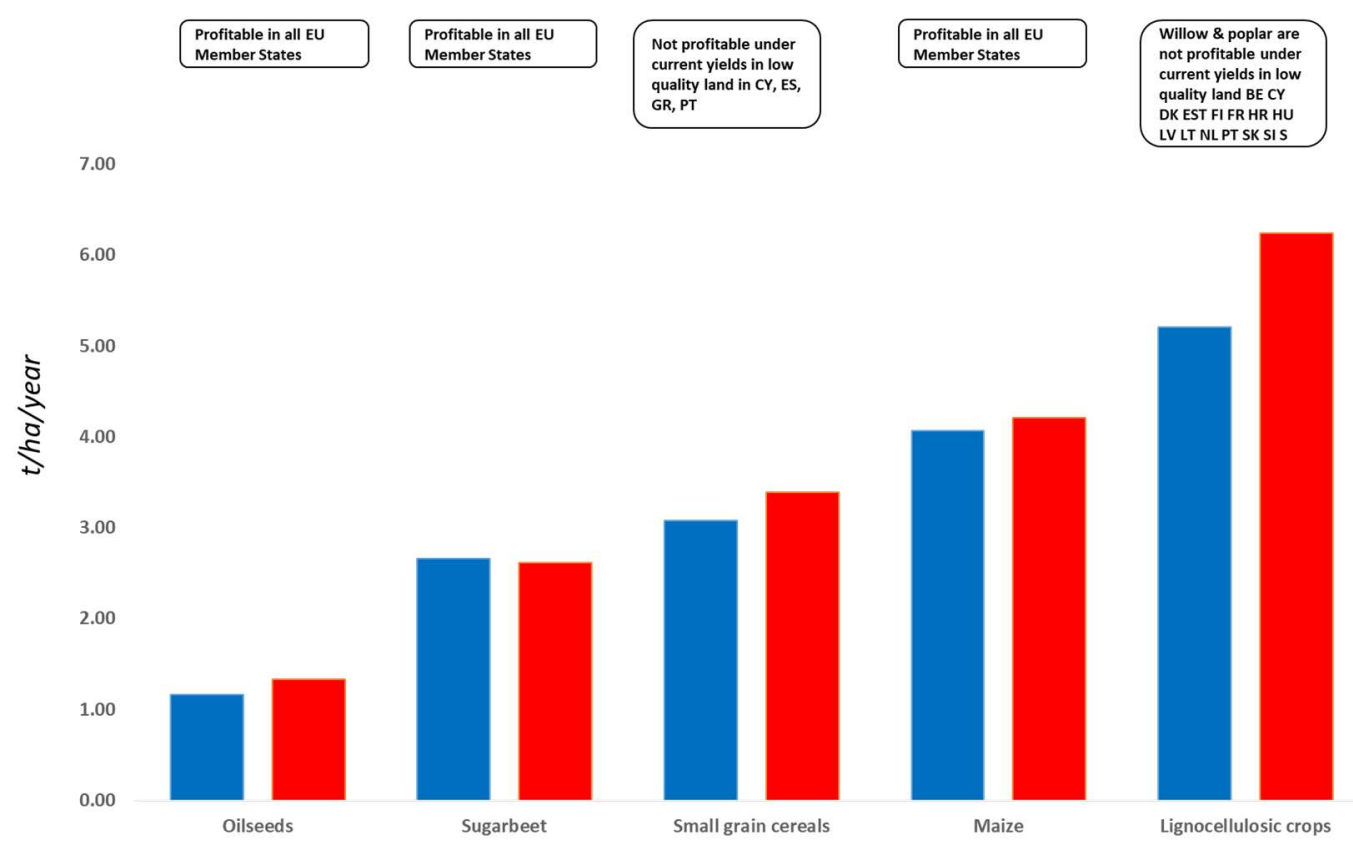

Figure 5. Crop yields ( $\mathrm{t} / \mathrm{ha}$ /year) required to breakeven Total Production Costs (TPC) and Gross Sales Income (GSI), meaning PI = 1 . In blue the values for low quality land and in red the ones for average farming land.

\subsubsection{Market selling prices}

This section estimates market selling prices for which the crops can be profitable for farmers. These values can be considered as 'farm gate' base prices for the industries interested in the crops as feedstocks to their processes. (Figure 6) 


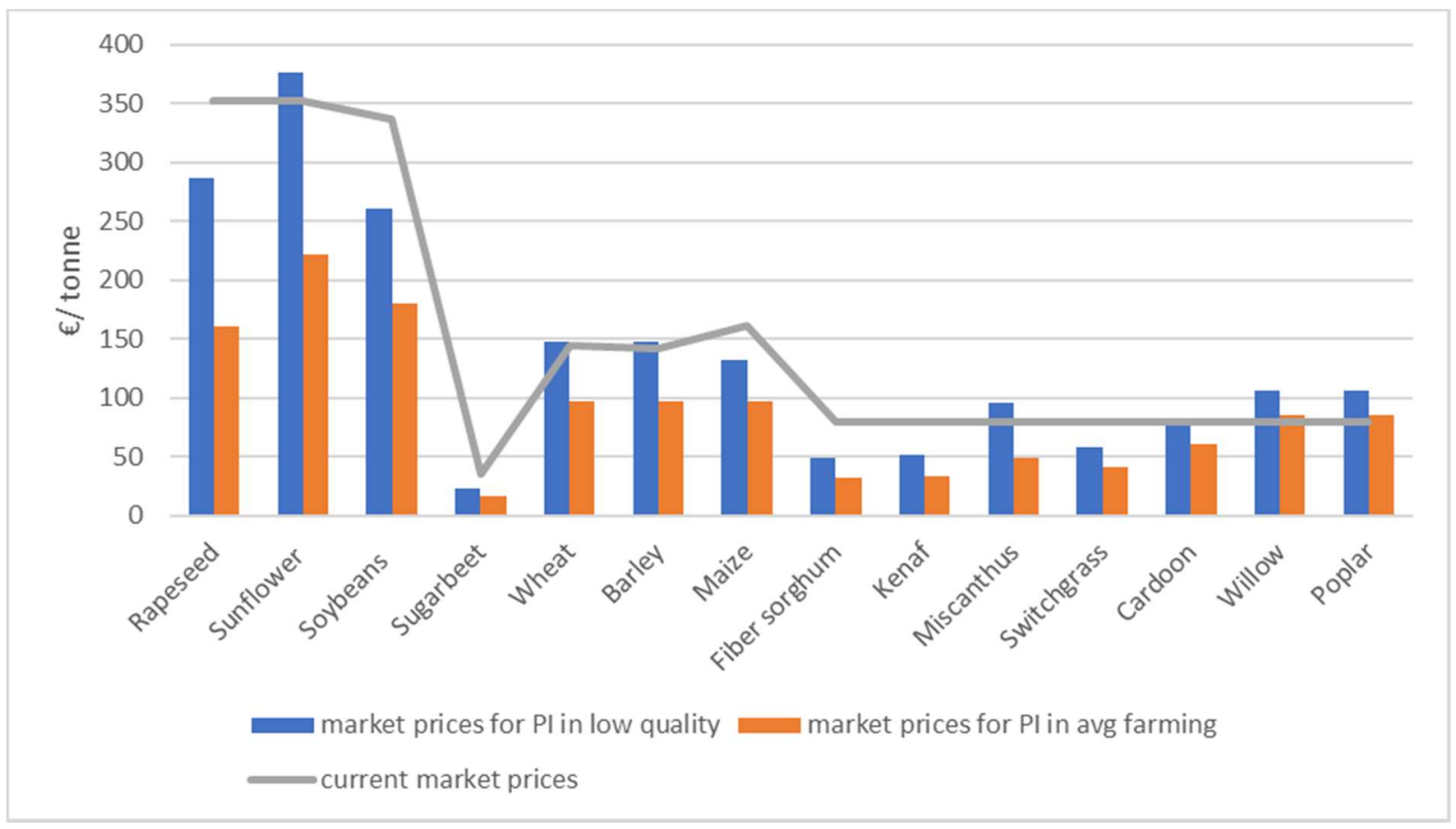

Figure 6. Market selling prices (€/tonne) required to breakeven Total Production Costs (TPC) and Gross Sales Income (GSI), meaning PI = 1 (in bold current market selling prices).

Breakeven market selling prices for rapeseed and soy cultivation in low quality land in EU should be at least 287 and $260 € /$ tonne respectively, while for sunflower the base price is $377 € /$ tonne so that the crops are economic options for farmers. The large difference observed for sunflower is due to its lower yields. Rapeseed is not profitable in low quality land in Italy, Greece and Netherlands as selling prices are lower than production costs due to low yields. The situation is similar for sunflower on low quality land in Italy, Spain and Portugal while soy is unprofitable only in Greece and Poland. The respective selling price for the average farming land type is estimated at $222 € /$ tonne.

Breakeven market selling prices for cultivating cereals in low quality land should be above $148 € /$ tonne. Still, wheat is not profitable on low quality land in Cyprus and Portugal. The situation is similar for barley on low quality land in Cyprus, Spain, Greece, Italy, Poland, Portugal and Romania. The respective selling price for average farming land is estimated at $98 € /$ tonne.

Sugar beet and maize are profitable crops for all EU countries. The respective breakeven market selling prices for low quality and average farming land types are estimated for the first at $24 € /$ tonne and $16 € /$ tonne and for the second at $132 € /$ tonne and $98 € /$ tonne.

Breakeven market selling prices for fiber sorghum and kenaf in low quality and average farming land are estimated at $52 € /$ tonne and $39 € /$ tonne. Values for switchgrass are similar.

The respective market selling prices for the other lignocellulosic crops are estimated at $79 € /$ tonne (low quality) and $61 € /$ tonne (average) for cardoon, at $96 € /$ tonne (low quality) and $49 € /$ tonne (average) for miscanthus and at $106 € /$ tonne (low quality) and $85 € /$ tonne (average) for poplar and willow.

\subsection{Future Improvements}

This section builds on the estimated values presented above and analyses how future improvements in crop yield increases or crop cultivation in low quality land; could improve profitability.

\subsubsection{Impact of increasing crop yields in net farm profits}

The estimated figures in Figure 7 match the ones from Figure 4 and are averaged over all countries and with median market prices (2018) per crop and Member State. The additional net farm profit illustrated after each section in full colour results from a $10 \%$ increase in the yielding capacity of the 
crops. This yield improvement represents an annual yield increase of $0.7 \%$ and is easily attainable by 2030 [16] through use of better varieties and improved crop management practices.

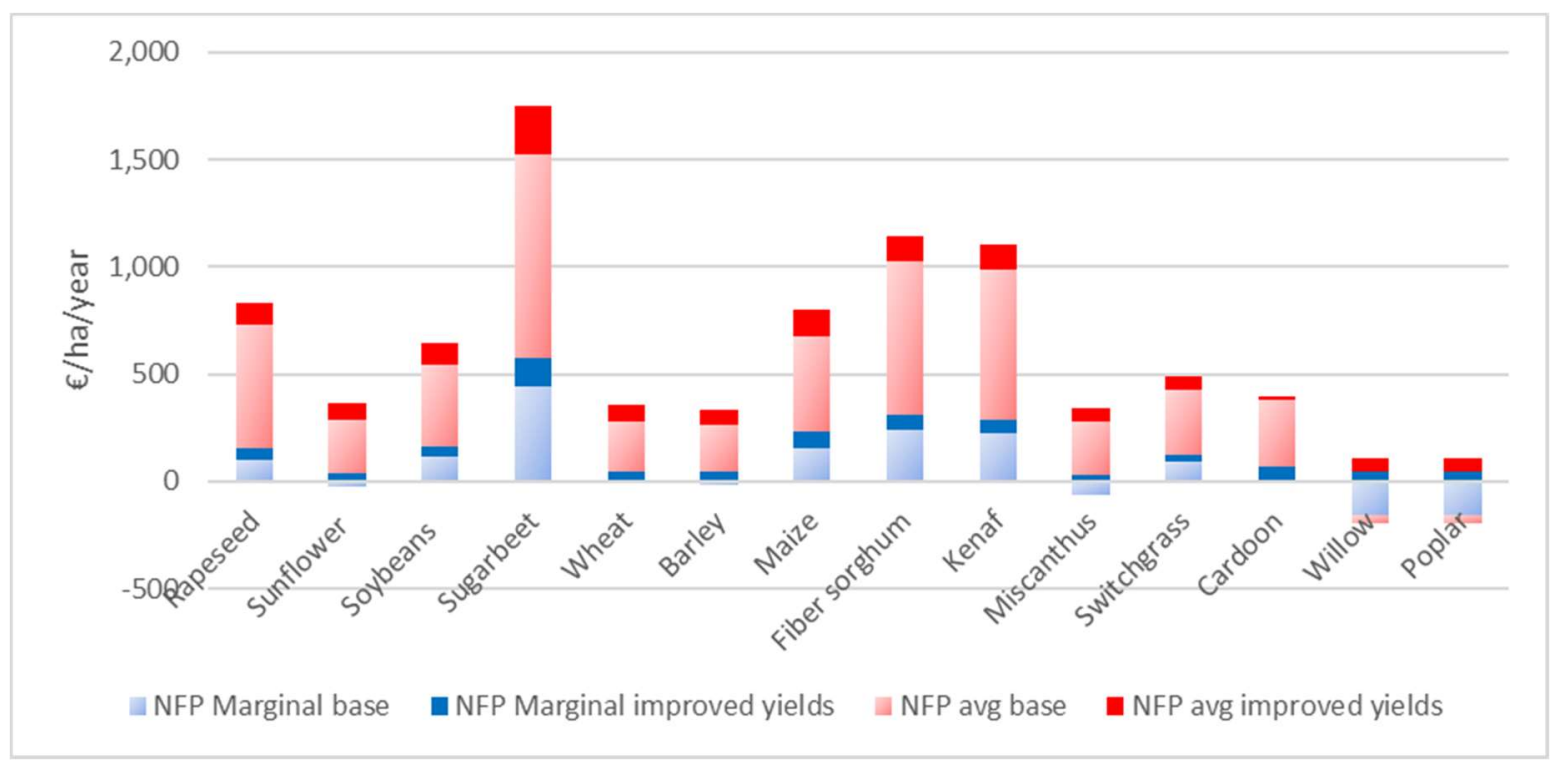

Figure 7. Cumulative net farm profit ( $€$ /ha/year) improvements from a yield increase of $10 \%$ till 2030 (in fade colours the baseline and in full colour the respective increase in profit by the higher yields for each land type). Median market prices have been used as reference values in the analysis, see Table 6 .

As expected, all crops exhibit increases to their net farm profit when yields increase. The most interesting case is that of willow and poplar when cultivated on both average farming and low quality land. Both crops present positive values for net farm profit when their yields increase by $10 \%$. That observation is also made for sunflower and miscanthus in low quality land. Wheat, barley and cardoon also become profitable in such lands when compared to a zero profit state under current yields.

\subsubsection{Land Use of Low Quality Land}

Estimates from previous studies [1,3,4,12] addressing availability of low quality land in EU by 2030 range between 7-40 million ha of biomass. The European project S2Biom has estimated that a total of 18.3 million ha can be available in EU by 2030. This comprises of 13.7 million ha of land with biophysical (land which is difficult to access, has poor soil or climate, etc.) low quality conditions and 4.6 million ha of land which will be released and left unused due to low economic competitiveness of existing production systems (broadly referred to as socio-economic low quality conditions). This section provides estimates of the economic added value from cultivating such land types with the crops under study when they are profitable options. Calculations included values (for yields, production costs, etc.) on low quality land for the 13.7 million ha with biophysical restrictions and average farming values for the 4.6 million ha, with socio-economic marginality. For each specific 'crop and country' combination, the Net Farm Profit ( $€ /$ ha/year) has been calculated and multiplied by the estimated available land to estimate the potential added value for the farmers' income by crop and country (Figure 8).

Figure 9 presents the net farm profit per country and the results derive as combined outcome of land availability in low quality land types, crop suitability, yields and prevailing selling prices. 

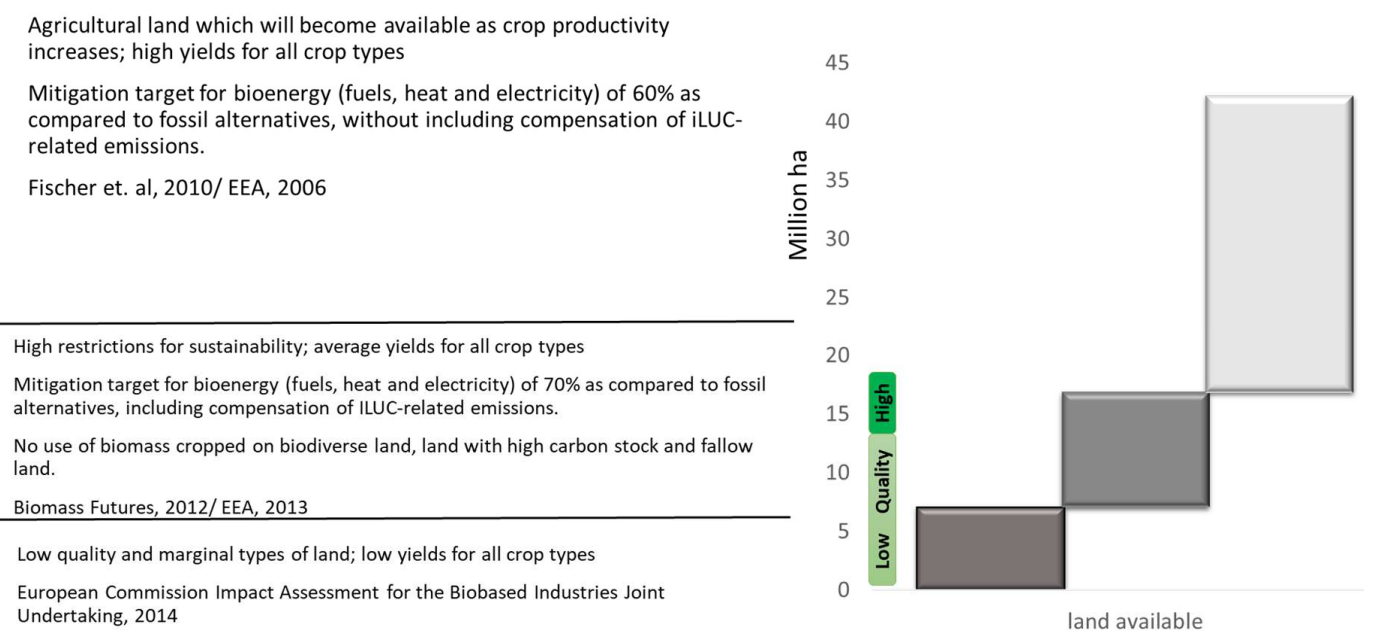

Figure 8. Land availability (million ha) for dedicated non-food lignocellulosic crops in EU (in green the estimates from S2Biom for availability of low and high quality land available by 2030). Adapted from Panoutsou et al., D8.2. Vision for 1 billion dry tonnes lignocellulosic biomass as a contribution to biobased economy by 2030 in Europe.

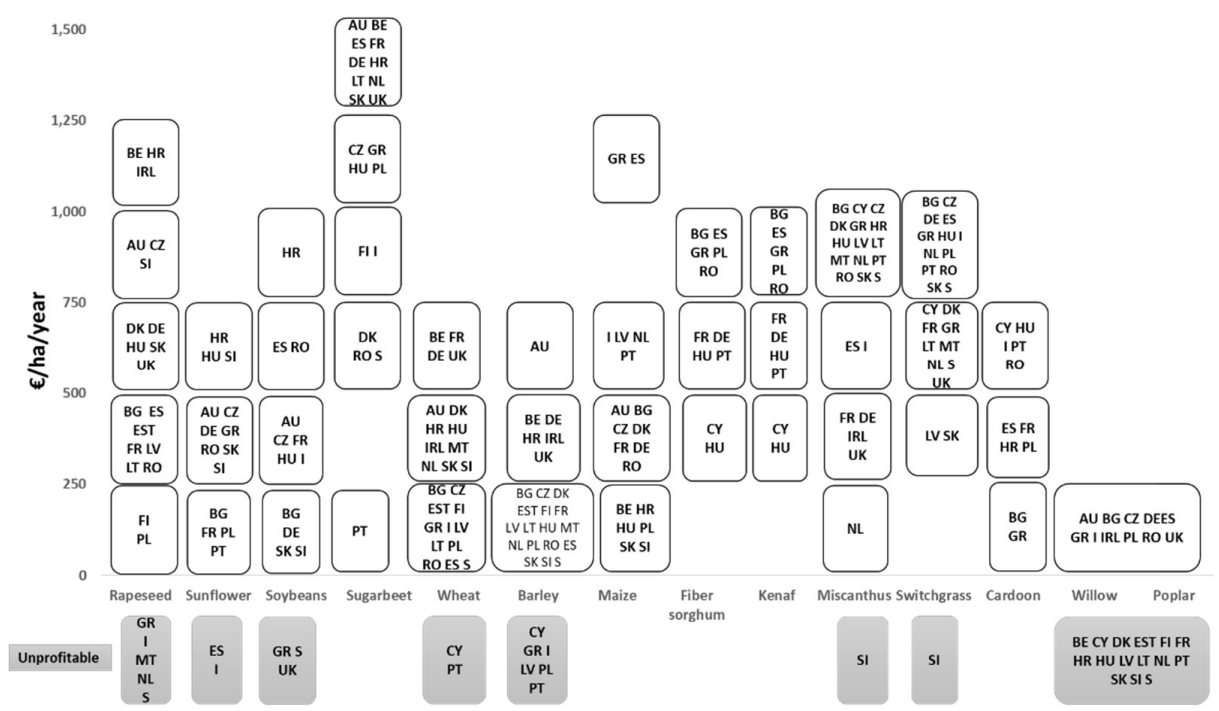

Figure 9. Net farm profit (€/ha/year) from the cultivation of profitable crop options (as presented in Table 6) in low quality land of EU countries. When a country is not shown, it means that the crop is not cultivated in a significant part.

\section{Conclusions}

Crop production in EU comprises a variety of crops which can form the resource base for food, feed, fine chemicals, pharmaceuticals, building materials and biofuels. Food and feed will remain top priorities for future cropping systems however the non-food, non-feed markets are also very important and are expected to contribute significantly towards future low carbon bioeconomies.

With the demand for sustainable and locally sourced raw materials rising it is significant for decision makers to understand the current crop options and appreciate how these can be turned into economic opportunities for both farmers and industrial actors. Hence, crop yields, farm gate production costs, profitability and the likelihood to produce more by exploiting unused, low quality land are important as both industry and policy stakeholders seek technically sound evidence to inform their plans and decision making.

The results from the work presented in this paper can inform on economically sustainable decisions for locally sourced crops as raw materials in Europe. They provide estimates for the costs 
and profitability of European crops and analyse how these can be influenced by yield increase through sustainable agronomic practices and cultivation in low quality land. This knowledge can also be used for future crop selection within the Common Agricultural Policy strategic plans and provide input for potential financial interventions required to make specific crops profitable options for farmers and the respective industries.

Among the crops under study, wheat, barley and oilseeds are profitable options under current market prices across EU countries and land types except for wheat in low quality land in Cyprus and Portugal and barley in Cyprus, Greece, Italy, Latvia, Poland and Portugal. Yields, above which the crops can become profitable across all land types have been estimated at 3-3.5 t/ha/year for cereals and 1-1.4 t/ha/year for oilseeds. Countries with high profitability per crop are presented in detail in Table 6. Among them, Austria, Hungary and UK exhibit very high values across all crops within the cereal and oilseeds categories.

Sugar beet and maize are also profitable across all the countries under study and land types since their high yielding potential counterbalances their respectively high production costs. Yield levels, above which the crops become profitable are estimated at $2.6-2.8 \mathrm{t} / \mathrm{ha} / \mathrm{year}$ and $4-4.5 \mathrm{t} / \mathrm{ha} /$ year, respectively.

Lignocellulosic crops present low to average profitability for the three land types except for willow and poplar which are non-profitable on low quality land in Belgium, Croatia, Cyprus, Denmark, Estonia, Finland, France, Hungary, Latvia, Lithuania, Netherlands, Portugal, Slovakia, Slovenia and Sweden.

Based on the research work supporting this paper, important factors that influence profitability most, except yields, are market selling prices. For the latter, one should note that market selling prices for oilseeds in EU are at their highest levels due to market demand, at the time of writing this paper. During the last decade (2006-2015), they have ranged from 250 to $350 € /$ tonne. If the selling price drops to its ten-year low range then the production of rapeseed, sunflower and soybeans in low quality land would become uneconomic in most countries. The situation is similar for small grain cereals including wheat and barley but with much smaller price ranges, from 120 to $150 € /$ tonne. If selling prices drop to the lower levels experienced in the last ten years, the cultivation of these crops in low quality land would also become uneconomic.

Finally, concerning the opportunity of increasing the amount of land available by cultivating low quality land types the analysis presented in this paper shows that there are good prospects for all the crops under study with variable annual next farm profits for specific 'crop-country' cases. Most of the analysed cases can result to annual net farm profits within a range of 250-750€/ha/year; which represent an income for European farmers that is in most cases comparable to cereals in the respective countries.

The increasing demand from the variable bioeconomy sectors will steer developments in the rehabilitation of low quality land around Europe. Such land types however have restrictions due to either low fertility, steepness of terrain, unfavourable climatic conditions and/or difficult market accessibility, small holdings and poor infrastructure. Therefore, substantial efforts and time would be required to (re)turn them to productivity. These elements should be carefully addressed in a cost benefit analysis when planning for the economic use of such land types.

Future research for the economic prospects of crops in low quality land should focus on 'case specific' situations since there are variations in the types and conditions which affect the quality of land. Yields and cost relevant parameters (including prevailing market prices) used in the analysis should be as close as possible to local and regional conditions of the case study analysed.

Author Contributions: Conceptualization, C.P. and E.A.; Methodology, C.P.; Validation, C.P. and E.A.; Formal Analysis, C.P.; Investigation, C.P.; Resources, C.P. and E.A.; Data Curation, C.P. and E.A.; Writing-Original Draft Preparation, C.P.; Writing-Review \& Editing, C.P. All authors have read and agreed to the published version of the manuscript.

Funding: "This research was funded by the European Commission, in Biomass Policies, grant number [SI2.64592]" and in S2Biom, grant number [608622].

Conflicts of Interest: The authors declare no conflict of interest. 


\section{Appendix A}

Table A1. Land rent (€/ha) for average farming and low-quality land.

\begin{tabular}{|c|c|c|c|c|c|c|c|c|c|c|c|c|c|c|c|c|c|c|c|c|c|c|c|c|c|c|c|c|c|}
\hline & $\mathrm{AU}$ & BE & BG & $C Y$ & $\mathrm{CZ}$ & DK & EST & $\begin{array}{l}\text { FIN } \\
\end{array}$ & FR & $\mathrm{DE}$ & GR & HR & HUN & I & $\begin{array}{ll}\text { IRL } \\
\end{array}$ & LV & LT & LUX & MLT & $\mathrm{NL}$ & PL & PT & RO & SP & SK & SI & $\mathrm{s}$ & UK & Median \\
\hline Average & 209 & 300 & 50 & 135 & 50 & 350 & 50 & 113 & 300 & 300 & 350 & 60 & 60 & 400 & 190 & 15 & 15 & 168 & 135 & 600 & 250 & 250 & 50 & 300 & 20 & 20 & 350 & 201 & 179 \\
\hline Low quality & 143 & 200 & 70 & 92 & 28 & 300 & 27 & 62 & 250 & 250 & 200 & 40 & 45 & 350 & 185 & 10 & 10 & 162 & 92 & 400 & 150 & 100 & 30 & 200 & 10 & 10 & 200 & 194 & 121.5 \\
\hline
\end{tabular}

Table A2. Labour costs for skilled and unskilled employment $(€ / h)$.

\begin{tabular}{|c|c|c|c|c|c|c|c|c|c|c|c|c|c|c|c|c|c|c|c|c|c|c|c|c|c|c|c|c|c|}
\hline & $\mathrm{AU}$ & BE & BG & $\mathrm{CY}$ & $\mathrm{CZ}$ & DK & EST & FIN & FR & DE & GR & HR & HUN & I & IRL & LV & LT & LUX & MLT & $\mathrm{NL}$ & PL & PT & RO & SP & SK & SI & $\mathrm{s}$ & UK & Median \\
\hline Skilled & 15 & 15 & 5.5 & 6 & 7 & 30 & 6 & 16.7 & 16 & 15.5 & 7.1 & 7.1 & 6 & 14.38 & 13 & 5 & 5 & 13.99 & 7.5 & 19 & 7.7 & 4.76 & 4 & 14.4 & 5.5 & 6.8 & 22 & 14.42 & 7.6 \\
\hline Unskilled & 6.85 & 9.93 & 0.69 & 4.2 & 3.49 & 14.3 & 1.59 & 8.8 & 8.27 & 9 & 3.8 & 2.82 & 2.17 & 6.37 & 8.5 & 1 & 3.57 & 12.4 & 3.5 & 11.1 & 1.34 & 2.6 & 2.17 & 4 & 2.46 & 4.84 & 10.35 & 8.6 & 4.1 \\
\hline $\begin{array}{l}\text { Average (FADN, } \\
2017 \text { values) }\end{array}$ & 10.925 & 12.4653 & 53.095 & 5.1 & 5.245 & 22.1 & 3.8 & 12.8 & 12.135 & 12.25 & 5.45 & 4.96 & 4.09 & 10.38 & 10.8 & 3 & 4.29 & 13.2 & 5.5 & 15.1 & 4.52 & 3.68 & 3.09 & 9.19 & 3.98 & 5.82 & 16.175 & 11.51 & 5.66 \\
\hline
\end{tabular}

Table A3. Crop yields (t/ha)- 2017 (average farming land).

\begin{tabular}{|c|c|c|c|c|c|c|c|c|c|c|c|c|c|c|c|c|c|c|c|c|c|c|c|c|c|c|c|c|c|}
\hline Oil crops & $\mathrm{AU}$ & BE & BG & $\mathrm{CY}$ & $\mathrm{CZ}$ & DK & EST & FIN & FR & $\mathrm{DE}$ & GR & HR & HUN & I & IRL & LV & LT & LUX & MLT & NL & PL & PT & RO & SP & SK & SI & $\mathrm{s}$ & UK & Median \\
\hline Rapeseed & 3.3 & 4.3 & 2.5 & - & 3.5 & 3.9 & 2.0 & 1.5 & 3.0 & 3.9 & 1.5 & 2.7 & 2.5 & 2.4 & 3.6 & 2.4 & 2.1 & 3.4 & 0.0 & 3.0 & 3.0 & & 2.4 & 2.6 & 2.6 & 2.4 & 2.7 & 3.0 & 2.7 \\
\hline Sunflower & 2.4 & & 2.2 & - & 2.3 & - & - & - & 2.1 & 2.4 & 2.4 & 3.2 & 2.5 & 2.2 & - & - & - & - & - & - & 1.8 & 0.6 & 2.0 & 1.2 & 2.3 & 1.8 & - & - & 2.2 \\
\hline Soybeans & 2.0 & & 1.8 & - & 2.0 & - & - & - & 2.6 & 2.0 & 3.3 & 2.4 & 1.9 & 3.4 & - & - & - & - & - & - & 1.7 & & 2.2 & 2.8 & 1.4 & 1.7 & - & - & 2 \\
\hline \multicolumn{30}{|c|}{ Sugar and starch } \\
\hline Sugarbeet & 68 & 80 & - & - & 60 & 52 & & 40 & 85 & 64 & 61 & 52 & 53 & 53 & - & - & 55 & - & - & 78 & 58 & 25 & 37 & 79 & 56 & & 64 & 72 & 59 \\
\hline Wheat & 5 & 8 & 4 & 2 & 4 & 7 & 3 & 4 & 7 & 8 & 3 & 5 & 5 & 4 & 9 & 4 & 4 & 6 & 5 & 9 & 4 & 2 & 4 & 3 & 5 & 4 & 6 & 7 & 5 \\
\hline Barley & 8 & 8 & 4 & 1 & 4 & 6 & 3 & 4 & 6 & 7 & 3 & 4 & 4 & 4 & 8 & 3 & 3 & 6 & 4 & 7 & 4 & 2 & 3 & 4 & 4 & 4 & 5 & 6 & 4 \\
\hline Maize & 8 & 11 & 6 & - & 7 & 6 & 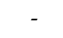 & - & 8 & 9 & 11 & 7 & 5 & 9 & - & - & 7 & 11 & 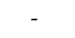 & 12 & 7 & 8 & 5 & 11 & 5 & 5 & - & - & 8 \\
\hline \multicolumn{30}{|l|}{ Lignocellulosic } \\
\hline Flax & 1.3 & 6.7 & 2.5 & - & - & - & 0.87 & & 1.36 & - & - & - & - & 1.15 & - & 2.5 & 1 & - & - & 6 & 2.6 & & 1.4 & - & - & - & - & 1.4 & 1.4 \\
\hline Hemp & - & - & - & - & - & - & - & - & 6.2 & - & - & - & 4.2 & - & - & - & - & - & - & - & 5 & & 0.9 & 3 & - & - & - & - & 4.2 \\
\hline Fiber sorghum & - & - & 15 & 15 & - & - & - & - & 15 & 12 & 15 & 15 & 15 & 15 & - & - & - & - & - & - & 15 & 15 & 15 & 15 & - & - & - & - & 15 \\
\hline Kenaf & - & - & 15 & 15 & - & - & - & - & 15 & 12 & 15 & 15 & 15 & 15 & - & 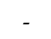 & - & - & - & - & 15 & 15 & 15 & 15 & - & - & - & - & 15 \\
\hline Miscanthus & - & - & 15 & 15 & 12 & 12 & - & - & 12 & 12 & 15 & 15 & 15 & 15 & 12 & 12 & 12 & 12 & 12 & 12 & 15 & 15 & 15 & 15 & 12 & & 13 & 10 & 12 \\
\hline Switchgrass & - & - & 15 & 15 & 12 & 12 & - & - & 12 & 12 & 15 & 15 & 15 & 15 & 12 & 12 & 12 & 12 & 12 & 12 & 15 & 15 & 15 & 15 & 12 & & 13 & 8 & 12 \\
\hline Cardoon & 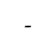 & 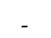 & 15 & 15 & & 12 & 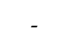 & - & 12 & & 15 & 15 & 15 & 15 & & & & & & 12 & 15 & 15 & 15 & 15 & & & & & 15 \\
\hline Willow & 8 & 8 & 8 & 8 & 8 & 8 & 8 & 8 & 8 & 8 & 8 & 8 & 8 & 8 & 8 & 8 & 8 & 8 & 8 & 8 & 8 & 8 & 8 & 8 & 8 & 8 & 8 & 8 & 8 \\
\hline Poplar & 8 & 8 & 8 & 8 & 8 & 8 & 8 & 8 & 8 & 8 & 8 & 8 & 8 & 8 & 8 & 8 & 8 & 8 & 8 & 8 & 8 & 8 & 8 & 8 & 8 & 8 & 8 & 8 & 8 \\
\hline
\end{tabular}

Table A4. Production costs for materials used in each crop for average farming conditions; in low quality land the respective costs are increased by $20 \%$.

\begin{tabular}{|c|c|c|c|c|c|c|c|c|c|c|c|c|c|c|c|c|}
\hline $\begin{array}{l}\text { Production costs } \\
\end{array}$ & Rapeseed & Sunflower & Soybean & Sugarbeet & Wheat & Barley & Maize & Flax & Hemp & Fiber sorghum & Kenaf & Miscanthus an & Switchgrass an & Cardoon an & Switchgrass an & Cardoon ar \\
\hline Materials ( $(\mathbf{h} / \mathbf{h a})$ & 233 & 182 & 200 & 500 & 250 & 250 & 400 & 130 & 150 & 200 & 217 & 100 & 100 & 50 & 100 & 50 \\
\hline
\end{tabular}


Table A5. Market selling prices (€).

\begin{tabular}{|c|c|c|c|c|c|c|c|c|c|c|c|c|c|c|c|c|c|c|c|c|c|c|c|c|c|c|c|c|}
\hline & AT & BE & BG & $\mathrm{CY}$ & $\mathrm{CZ}$ & DK & $\mathrm{EE}$ & FI & FR & $\mathrm{DE}$ & EL & HR & $\mathrm{HU}$ & IT & IE & LV & LT & LUX & MT & NL & PL & PT & RO & ES & SK & SI & SE & UK \\
\hline barley & 123 & 130 & 124 & 143 & 129 & 145 & 107 & 132 & 132 & 142 & 175 & 177 & 132 & 164 & 119 & 104 & 122 & 144 & 144 & 139 & 119 & 171 & 170 & 152 & 141 & 116 & 131 & 148 \\
\hline wheat & 142 & 143 & 127 & 228 & 115 & 140 & 129 & 131 & 152 & 153 & 243 & 156 & 144 & 225 & 110 & 126 & 132 & 161 & 161 & 138 & 130 & 170 & 149 & 181 & 129 & 144 & 141 & 147 \\
\hline maize & 125 & 75 & 137 & 207 & 132 & 212 & 207 & 212 & 146 & 144 & 206 & 116 & 130 & 174 & 212 & 207 & 162 & 207 & 207 & 132 & 126 & 153 & 220 & 179 & 120 & 120 & 157 & 212 \\
\hline oats & 107 & 116 & 110 & 464 & 106 & 140 & 82 & 113 & 90 & 139 & 158 & 166 & 128 & 192 & 109 & 89 & 105 & 152 & 152 & 94 & 99 & 143 & 203 & 139 & 109 & 151 & 117 & 130 \\
\hline Sugar-beet & 35 & 29 & 36 & 36 & 31 & 36 & 36 & 41 & 27 & 36 & 31 & 39 & 37 & 36 & 36 & 37 & 37 & 36 & 36 & 36 & 35 & 36 & 38 & 30 & 40 & 36 & 26 & 36 \\
\hline rapeseed & 378 & 463 & 294 & 385 & 305 & 343 & 336 & 354 & 323 & 340 & 394 & 527 & 346 & 201 & 489 & 299 & 313 & 385 & 385 & 227 & 301 & 394 & 258 & 476 & 342 & 535 & 298 & 365 \\
\hline Sunflower seed & 307 & 403 & 247 & 381 & 273 & 403 & 381 & 344 & 339 & 343 & 368 & 318 & 342 & 257 & 403 & 381 & 381 & 381 & 381 & 374 & 352 & 670 & 294 & 384 & 294 & 840 & 403 & 319 \\
\hline Soya seed & 370 & 337 & 233 & 330 & 381 & 337 & 330 & 337 & 359 & 337 & 38 & 443 & 323 & 276 & 337 & 330 & 330 & 330 & 330 & 337 & 240 & 337 & 362 & 404 & 233 & 317 & 337 & 337 \\
\hline STRAW average CAPRI & 155 & 70 & 39 & 32 & 62 & 64 & 38 & 64 & 35 & 81 & 51 & 39 & 50 & 39 & 23 & 38 & 38 & 93 & 32 & 93 & 38 & 32 & 39 & 32 & 67 & 39 & 64 & 68 \\
\hline
\end{tabular}

Table A6. Fertilisers $€ / 100$ kg.

\begin{tabular}{lcccccccccccccccccccccccccccc}
\hline & AU & BE & BG & CY & CZ & DK & EST & FIN & FR & GE & GR & HR & HUN & I & IRL & LV & LI & LUX & MLT & NL & PL & PT & RO & SP & SK & SI & S & UK \\
\hline N & 48 & 48 & 18 & 45 & 23 & 45 & 29 & 45 & 45 & 45 & 44 & 44 & 43 & 45 & 45 & 28 & 28 & 53 & 45 & 45 & 18 & 46 & 18 & 28 & 28 & 47 & 45 & 54 \\
\hline P2O5 & 49 & 49 & 21 & 51 & 12 & 49 & 24 & 49 & 51 & 51 & 49 & 49 & 20 & 49 & 49 & 20 & 28 & 49 & 49 & 49 & 20 & 49 & 21 & 20 & 20 & 47 & 49 & 47 \\
\hline K2O & 18 & 36 & 21 & 40 & 17 & 29 & 17 & 33 & 37 & 35 & 33 & 33 & 20 & 38 & 33 & 14 & 21 & 34 & 33 & 41 & 20 & 34 & 21 & 20 & 20 & 30 & 33 & 32 \\
\hline
\end{tabular}

Table A7. Annual Total Productions costs (TPC) per crop and country (in $€ /$ ha) in average farming land.

\begin{tabular}{|c|c|c|c|c|c|c|c|c|c|c|c|c|c|c|c|c|c|c|c|c|c|c|c|c|c|c|c|c|c|}
\hline & $\mathrm{AU}$ & BE & BG & $\mathrm{CY}$ & $\mathrm{CZ}$ & DK & EST & FIN & FR & $\mathrm{DE}$ & GR & HR & HUN & I & IRL & LV & LT & LUX & MLT & NL & PL & PT & RO & SP & SK & SI & $\mathrm{s}$ & UK & Median \\
\hline Rapeseed & 500 & 604 & 296 & & 311 & 701 & 301 & 415 & 599 & 601 & 613 & 318 & 314 & 687 & 484 & 262 & 273 & 481 & 397 & 917 & 503 & & 300 & 577 & 274 & 287 & 669 & 498 & 482 \\
\hline Sunflower & 458 & & 247 & & 265 & & & & 558 & 561 & 566 & 272 & 266 & 645 & & & & & & & 455 & 455 & 252 & 533 & 226 & 241 & 632 & & 455 \\
\hline Soybeans & 467 & & 263 & & 278 & & & & 566 & 568 & 580 & 285 & 281 & 654 & & & & & & & 470 & & 267 & 544 & 241 & 254 & 636 & & 467 \\
\hline Sugarbeet & 846 & 956 & & & 616 & 1,127 & 597 & 773 & 952 & 953 & 918 & 622 & 611 & 1,030 & & & 569 & & & 1,288 & 807 & 796 & 589 & 915 & 570 & & 1,052 & 845 & \\
\hline Wheat & 505 & 607 & 311 & 409 & 323 & 695 & 315 & 419 & 603 & 605 & 624 & 331 & 327 & 694 & 489 & 276 & 285 & 482 & 409 & 917 & 516 & 516 & 314 & 586 & 287 & 297 & 669 & 503 & 845 \\
\hline Barley & 505 & 607 & 311 & 409 & 323 & 695 & 315 & 419 & 603 & 605 & 624 & 331 & 327 & 694 & 489 & 276 & 285 & 482 & 409 & 917 & 516 & 516 & 314 & 586 & 287 & 297 & 669 & 503 & 486 \\
\hline Maize & 702 & 815 & 471 & & 495 & 940 & & & 806 & 810 & 798 & 501 & 493 & 888 & & & 455 & 697 & & 1,135 & 682 & 682 & 477 & 771 & 454 & 474 & & & 486 \\
\hline Fiber sorghum & & & 271 & 382 & & & & & 606 & 610 & 598 & 301 & 293 & 688 & & & & & & & 482 & 482 & 277 & 571 & & & & & 412 \\
\hline Kenaf & & & 288 & 399 & & & & & 623 & 627 & 615 & 318 & 310 & 705 & & & & & & & 499 & 499 & 294 & 588 & & & & & 521 \\
\hline Miscanthus (annualised) & & & 178 & 297 & 209 & 697 & & & 538 & 542 & 512 & 213 & 203 & 614 & 418 & 144 & 167 & 435 & 296 & 875 & 392 & 392 & 185 & 492 & 164 & 191 & 630 & 435 & \\
\hline Switchgrass (annualised) & & & 121 & 232 & 145 & 590 & & & 456 & 460 & 448 & 151 & 143 & 538 & 339 & 87 & 105 & 347 & 232 & 785 & 332 & 332 & 127 & 421 & 104 & 124 & 538 & 354 & 482 \\
\hline Cardoon (annualised) & & & 521 & 632 & & & & & 856 & 860 & 848 & 551 & 543 & 938 & & & & & & & 732 & 732 & 527 & 821 & & & & & 499 \\
\hline Willow & 702 & 815 & 471 & 582 & 495 & 940 & 479 & 625 & 806 & 810 & 798 & 501 & 493 & 888 & 689 & 437 & 455 & 697 & 582 & 1,135 & 682 & 682 & 477 & 771 & 454 & 474 & 888 & 704 & 392 \\
\hline Poplar & 702 & 815 & 471 & 582 & 495 & 940 & 479 & 625 & 806 & 810 & 98 & 501 & 493 & 888 & 689 & 437 & 455 & 697 & 582 & 1,135 & 682 & 682 & 477 & 771 & 454 & 474 & 888 & 704 & 332 \\
\hline
\end{tabular}


Table A8. Annual Total Productions costs (TPC) per crop and country (in $€ /$ ha) in low quality land.

\begin{tabular}{|c|c|c|c|c|c|c|c|c|c|c|c|c|c|c|c|c|c|c|c|c|c|c|c|c|c|c|c|c|c|}
\hline & $\mathrm{AU}$ & BE & BG & $\mathrm{CY}$ & $\mathrm{CZ}$ & DK & EST & FIN & FR & $\mathrm{DE}$ & GR & HR & HUN & I & IRL & LV & LT & LUX & MLT & $\mathrm{NL}$ & PL & PT & RO & SP & SK & SI & $\mathrm{s}$ & UK & Median \\
\hline Rapeseed & 480 & 551 & 363 & & 336 & 697 & 325 & 411 & 595 & 597 & 509 & 345 & 345 & 684 & 526 & 303 & 314 & 521 & 401 & 763 & 450 & & 326 & 524 & 311 & 323 & 565 & 538 & 465 \\
\hline Sunflower & 428 & & 304 & & 279 & & & & 545 & 547 & 453 & 288 & 287 & 632 & & & & & & & 392 & 342 & 268 & 470 & 253 & 267 & & & 342 \\
\hline Soybeans & 441 & & 323 & & 296 & & & & 556 & 558 & 470 & 305 & 306 & 644 & & & & & & & 410 & & 287 & 484 & 271 & 284 & & & 67 \\
\hline Suga & & 956 & 7 & 756 & 694 & 1177 & 674 & 822 & 1002 & 1003 & 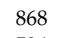 & & 696 & 1080 & 919 & 648 & 664 & 927 & 761 & 88 & & 7 & & & & 82 & 1002 & 938 & \\
\hline & & & & & & & & & & & & & & 6 & & & & & & & & & & & & & & & \\
\hline & & & & & & & & & & 605 & & & & & & & & & & & & & & & & & & & \\
\hline Maiz & & $7 \mathrm{~s}$ & $5 ?$ & 61 & 55 & 9 & 5 & 654 & 8 & 840 & 7 & 5 & 558 & 918 & 764 & 5 & 530 & 771 & 619 & 1015 & 662 & 612 & 537 & 7 & 524 & 544 & 18 & & 658 \\
\hline sorghu & & 4 & & & 29 & 652 & 37 & 4 & $\pi$ & 53 & & 3 & 38 & 61 & 4 & 3 & & 537 & 3 & 6 & 417 & & & & 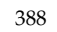 & 53 & & & 414 \\
\hline & & 5 & 3 & & & 6 & & 4 & 55 & & & 3 & 404 & & 4 & 3 & & & 3 & & & & & & & & & & 435 \\
\hline & & 46 & 21 & & 2 & & 18 & 32 & & 5 & & 2 & & & 4 & 15 & & & 2 & & 312 & 262 & & & 4 & 201 & & 48 & 20 \\
\hline Swit & 23 & 32 & 18 & 399 & 126 & 5 & 22 & 2 & 3 & & 3 & 2 & & 4 & 297 & 2 & & 39 & 1 & & 245 & 252 & & & 250 & 204 & & 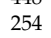 & 253 \\
\hline & 66 & 719 & 7 & & 63 & & & 5 & & & & 6 & & & & & & 66 & - & & & & & & & & & & 57 \\
\hline & & $72 ?$ & 5 & & & & & & & & & & & & & & & & 6 & & & & & & & & & & 654 \\
\hline Pop & 644 & 727 & 595 & 7 & 537 & 892 & 613 & 652 & 778 & 771 & 713 & 608 & 624 & 852 & 70 & 61 & 537 & 779 & 604 & 91 & 657 & 651 & 54 & 734 & 628 & 593 & 732 & 674 & 654 \\
\hline
\end{tabular}

Table A9. Profitability (euro/ha/year) in average farming land.

\begin{tabular}{|c|c|c|c|c|c|c|c|c|c|c|c|c|c|c|c|c|c|c|c|c|c|c|c|c|c|c|c|c|}
\hline & $\mathrm{AU}$ & BE & BG & $\mathrm{CY}$ & $\mathrm{CZ}$ & DK & EST & FIN & FR & DE & GR & HR & HUN & I & IRL & LV & LT & LUX & MLT & NL & PL & PT & RO & SP & SK & SI & $\mathrm{s}$ & UK \\
\hline Rapeseed & 748 & 1387 & 439 & & 756 & 637 & 371 & 116 & 370 & 725 & -22 & 1104 & 556 & -205 & 1276 & 456 & 385 & 828 & -397 & -236 & 400 & & 319 & 660 & 615 & 997 & 136 & 597 \\
\hline Sunflower & 279 & & 296 & & 366 & & & & 154 & 255 & 317 & 746 & 589 & -80 & & & & & & & 178 & -53 & 336 & -72 & 450 & 1271 & & \\
\hline Soybeans & 273 & & 156 & & 484 & & & & 368 & 106 & -454 & 778 & 333 & 284 & & & & & & & -60 & & 530 & 587 & 85 & 285 & & \\
\hline Sugarbeet & 1554 & 1385 & & & 1290 & 760 & -597 & 899 & 1369 & 1353 & 967 & 1412 & 1339 & 880 & & & 1469 & & & 1534 & 1249 & 98 & 823 & 1514 & 1687 & & 654 & 1750 \\
\hline Wheat & 261 & 585 & 223 & -9 & 174 & 327 & 111 & 79 & 507 & 619 & 56 & 434 & 336 & 161 & 501 & 215 & 283 & 548 & 461 & 283 & 56 & -227 & 208 & 30 & 307 & 336 & 149 & 585 \\
\hline Barley & 515 & 410 & 148 & -202 & 223 & 132 & 39 & 96 & 229 & 332 & -134 & 324 & 201 & -87 & 415 & 5 & 118 & 310 & 168 & 56 & -88 & -208 & 213 & -38 & 235 & 167 & -14 & 356 \\
\hline Maize & 311 & 18 & 405 & & 429 & 311 & & & 391 & 458 & 1386 & 253 & 209 & 626 & & & 744 & 1539 & & 436 & 149 & 587 & 513 & 1252 & 158 & 174 & & \\
\hline Fiber sorghum & & & 854 & 743 & & & & & 519 & 291 & 527 & 824 & 832 & 437 & & & & & & & 643 & 643 & 848 & 554 & & & & \\
\hline Kenaf & & & 837 & 726 & & & & & 502 & 274 & 510 & 807 & 815 & 420 & & & & & & & 626 & 626 & 831 & 537 & & & & \\
\hline Miscanthus & & & 947 & 828 & 691 & 203 & & & 362 & 358 & 613 & 912 & 922 & 511 & 482 & 756 & 733 & 465 & 604 & 25 & 733 & 733 & 940 & 633 & 736 & -191 & 345 & 315 \\
\hline Switchgras & & & 1004 & 893 & 755 & 310 & & & 444 & 441 & 677 & 974 & 982 & 587 & 562 & 813 & 795 & 553 & 668 & 115 & 793 & 793 & 998 & 704 & 796 & -124 & 437 & 246 \\
\hline Cardoon & & & 604 & 493 & & & & & 44 & & 277 & 574 & 582 & 187 & & & & & & & 393 & 393 & 598 & 304 & & & & \\
\hline Willow & -102 & -215 & 129 & 18 & 105 & -340 & 121 & -25 & -206 & -210 & -198 & 99 & 107 & -288 & -89 & 163 & 145 & -97 & 18 & -535 & -82 & -82 & 123 & -171 & 146 & 126 & -288 & -104 \\
\hline Poplar & -102 & -215 & 129 & 18 & 105 & -340 & 121 & -25 & -206 & -210 & -198 & 99 & 107 & -288 & -89 & 163 & 145 & -97 & 18 & -535 & -82 & -82 & 123 & -171 & 146 & 126 & -288 & -104 \\
\hline
\end{tabular}


Table A10. Profitability (euro/ha/year) in low quality land.

\begin{tabular}{|c|c|c|c|c|c|c|c|c|c|c|c|c|c|c|c|c|c|c|c|c|c|c|c|c|c|c|c|c|}
\hline & $\mathrm{AU}$ & BE & BG & $\mathrm{CY}$ & $\mathrm{CZ}$ & DK & EST & FIN & FR & DE & GR & HR & HUN & I & IRL & LV & LT & LUX & MLT & NL & PL & PT & RO & SP & SK & SI & $\mathrm{s}$ & UK \\
\hline Rapeseed & 767 & 1187 & 389 & & 734 & 537 & 349 & 65 & 270 & 625 & -172 & 1094 & 536 & -605 & 1256 & 446 & 375 & 822 & -440 & -536 & 200 & & 279 & 360 & 605 & 987 & -164 & 590 \\
\hline Sunflo & 308 & & 240 & & 352 & & & & 167 & 269 & 430 & 730 & 568 & -66 & & & & & & & 242 & 60 & 320 & -9 & 424 & 1245 & & \\
\hline s & 299 & & 96 & & 466 & & & & 3 & 116 & -344 & & 30 & 294 & & & & & & & & & & - & & 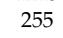 & \#VALUE! & \#VALUE! \\
\hline garbe & 1520 & 1385 & & & 1212 & 710 & -674 & 850 & 1319 & 1303 & 1017 & 1332 & 12 & 8 & & & 74 & & & 1634 & 1249 & 8 & 743 & 1514 & 1597 & & 704 & 1657 \\
\hline Whea & 277 & 635 & 153 & - & 146 & 3 & 84 & 80 & 507 & 619 & 156 & 404 & 3 & 161 & 456 & 170 & 238 & 504 & 454 & 433 & 106 & -127 & 8 & 1014 & 267 & 296 & 49 & 442 \\
\hline Bar & 53 & 460 & 7 & -209 & 19 & 1 & 12 & 97 & 22 & 3 & - & 29 & 1 & -87 & 370 & -40 & 73 & 266 & 161 & 20 & -38 & -108 & 183 & 1 & 195 & 127 & 86 & 313 \\
\hline $\mathrm{M}$ & 297 & 38 & 30 & & 371 & 281 & & & & & 14 & 1 & 1 & 596 & & & 669 & 1465 & & 556 & & 6 & 33 & 1272 & 88 & 104 & & \\
\hline $\mathrm{Fir}$ & & & 77 & 6 & & & & & & 369 & & 7 & 7 & 513 & & & & & & & & & & & & & & \\
\hline $\mathrm{Ke}$ & & & 74 & 5 & & & & & & & & & & & & & & & & & & & & & & & & \\
\hline M & & & 90 & 8 & 693 & 23 & & & 39 & 38 & 74 & 91 & 91 & 5 & 467 & 74 & 71 & 45 & 62 & 20 & & & 94 & 713 & 72 & -2 & 475 & 302 \\
\hline & & & 93 & 72 & 774 & 3 & & & & 537 & 82 & & 8 & 68 & 603 & 663 & 76 & 50 & 706 & 398 & & & 1 & 794 & 650 & -204 & 648 & 346 \\
\hline 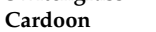 & & & 348 & 53 & & & & & 1 & & 3 & 49 & 591 & 26 & & & & & & & 423 & 5 & 564 & 285 & & & & \\
\hline Will & -44 & -127 & 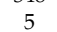 & -1 & 63 & -292 & -13 & -52 & -178 & -1 & -1 & - & -24 & - & -105 & -1 & 63 & -177 & - & - & - & 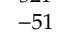 & & - & -28 & 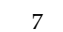 & -1 & -74 \\
\hline Poplar & -44 & -127 & 5 & -162 & 63 & -292 & -13 & -52 & -178 & -171 & -113 & -8 & -24 & -252 & -105 & -19 & 63 & -177 & -4 & -312 & -57 & -51 & 56 & -134 & $\begin{array}{l}-28 \\
-10\end{array}$ & 7 & $\begin{array}{l}-132 \\
-102\end{array}$ & $\begin{array}{l}-74 \\
\end{array}$ \\
\hline
\end{tabular}

Table A11. Profitability Index in average farming land.

\begin{tabular}{|c|c|c|c|c|c|c|c|c|c|c|c|c|c|c|c|c|c|c|c|c|c|c|c|c|c|c|c|c|}
\hline & $\mathrm{AU}$ & BE & BG & $\mathrm{CY}$ & $\mathrm{CZ}$ & DK & EST & FIN & FR & DE & GR & HR & HUN & I & IRL & LV & LT & LUX & MLT & NL & PL & PT & RO & SP & SK & SI & $\mathrm{s}$ & UK \\
\hline Rapeseed & 2.5 & 3.3 & 2.5 & & 3.4 & 1.9 & 2.2 & 1.3 & 1.6 & 2.2 & 1.0 & 4.5 & 2.8 & 0.7 & 3.6 & 2.7 & 2.4 & 2.7 & 0.0 & 0.7 & 1.8 & & 2.1 & 2.1 & 3.2 & 4.5 & 1.2 & 2.2 \\
\hline Sunflower & 1.6 & & 2.2 & & 2.4 & & & & 1.3 & 1.5 & 1.6 & 3.7 & 3.2 & 0.9 & & & & & & & 1.4 & 0.9 & 2.3 & 0.9 & 3.0 & 6.3 & & \\
\hline Soybeans & 1.6 & & 1.6 & & 2.7 & & & & 1.7 & 1.2 & 0.2 & 3.7 & 2.2 & 1.4 & & & & & & & 0.9 & & 3.0 & 2.1 & 1.4 & 2.1 & & \\
\hline Sugarbeet & 2.8 & 2.4 & & & 3.1 & 1.7 & 0.0 & 2.2 & 2.4 & 2.4 & 2.1 & 3.3 & 3.2 & 1.9 & & & 3.6 & & & 2.2 & 2.5 & 1.1 & 2.4 & 2.7 & 4.0 & & 1.6 & 3.1 \\
\hline Wheat & 1.5 & 2.0 & 1.7 & 1.0 & 1.5 & 1.5 & 1.4 & 1.2 & 1.8 & 2.0 & 1.1 & 2.3 & 2.0 & 1.2 & 2.0 & 1.8 & 2.0 & 2.1 & 2.1 & 1.3 & 1.1 & 0.6 & 1.7 & 1.1 & 2.1 & 2.1 & 1.2 & 2.2 \\
\hline Barley & 2.0 & 1.7 & 1.5 & 0.5 & 1.7 & 1.2 & 1.1 & 1.2 & 1.4 & 1.5 & 0.8 & 2.0 & 1.6 & 0.9 & 1.8 & 1.0 & 1.4 & 1.6 & 1.4 & 1.1 & 0.8 & 0.6 & 1.7 & 0.9 & 1.8 & 1.6 & 1.0 & 1.7 \\
\hline Maize & 1.4 & 1.0 & 1.9 & & 1.9 & 1.3 & & & 1.5 & 1.6 & 2.7 & 1.5 & 1.4 & 1.7 & & & 2.6 & 3.2 & & 1.4 & 1.2 & 1.9 & 2.1 & 2.6 & 1.3 & 1.4 & & \\
\hline Fiber sorghum & & & 4.1 & 2.9 & & & & & 1.9 & 1.5 & 1.9 & 3.7 & 3.8 & 1.6 & & & & & & & 2.3 & 2.3 & 4.1 & 2.0 & & & & \\
\hline Kenaf & & & 3.9 & 2.8 & & & & & 1.8 & 1.4 & 1.8 & 3.5 & 3.6 & 1.6 & & & & & & & 2.3 & 2.3 & 3.8 & 1.9 & & & & \\
\hline Miscanthus & & & 6.3 & 3.8 & 4.3 & 1.3 & & & 1.7 & 1.7 & 2.2 & 5.3 & 5.5 & 1.8 & 2.2 & 6.3 & 5.4 & 2.1 & 3.0 & 1.0 & 2.9 & 2.9 & 6.1 & 2.3 & 5.5 & 0.0 & 1.5 & 1.7 \\
\hline Switchgras & & & 9.3 & 4.8 & 6.2 & 1.5 & & & 2.0 & 2.0 & 2.5 & 7.4 & 7.9 & 2.1 & 2.7 & 10.3 & 8.6 & 2.6 & 3.9 & 1.1 & 3.4 & 3.4 & 8.8 & 2.7 & 8.7 & 0.0 & 1.8 & 1.7 \\
\hline Cardoon & & & 2.2 & 1.8 & & & & & 1.1 & & 1.3 & 2.0 & 2.1 & 1.2 & & & & & & & 1.5 & 1.5 & 2.1 & 1.4 & & & & \\
\hline Willow & 0.9 & 0.7 & 1.3 & 1.0 & 1.2 & 0.6 & 1.3 & 1.0 & 0.7 & 0.7 & 0.8 & 1.2 & 1.2 & 0.7 & 0.9 & 1.4 & 1.3 & 0.9 & 1.0 & 0.5 & 0.9 & 0.9 & 1.3 & 0.8 & 1.3 & 1.3 & 0.7 & 0.9 \\
\hline Poplar & 0.9 & 0.7 & 1.3 & 1.0 & 1.2 & 0.6 & 1.3 & 1.0 & 0.7 & 0.7 & 0.8 & 1.2 & 1.2 & 0.7 & 0.9 & 1.4 & 1.3 & 0.9 & 1.0 & 0.5 & 0.9 & 0.9 & 1.3 & 0.8 & 1.3 & 1.3 & 0.7 & 0.9 \\
\hline
\end{tabular}


Table A12. Profitability Index in low quality land.

\begin{tabular}{|c|c|c|c|c|c|c|c|c|c|c|c|c|c|c|c|c|c|c|c|c|c|c|c|c|c|c|c|c|}
\hline & $\mathrm{AU}$ & BE & BG & $\mathrm{CY}$ & $\mathrm{CZ}$ & DK & EST & FIN & FR & $\mathrm{DE}$ & GR & HR & HUN & I & IRL & LV & LT & LUX & MLT & NL & PL & PT & RO & SP & SK & SI & $\mathrm{s}$ & UK \\
\hline Rapeseed & 2.6 & 2.5 & 2.1 & & 3.2 & 1.7 & 2.1 & 1.1 & 1.4 & 1.9 & 0.8 & 4.3 & 2.6 & 0.4 & 3.5 & 2.6 & 2.3 & 2.7 & 0.0 & 0.6 & 1.3 & & 1.8 & 1.4 & 3.1 & 4.3 & 0.8 & 2.2 \\
\hline Sunflower & 1.7 & & 1.8 & & 2.3 & & & & 1.3 & 1.5 & 2.0 & 3.5 & 3.0 & 0.9 & & & & & & & 1.6 & 1.2 & 2.2 & 1.0 & 2.7 & 5.7 & & \\
\hline Soybeans & 1.7 & & 1.3 & & 2.6 & & & & 1.7 & 1.2 & 0.3 & 3.5 & 2.0 & 1.5 & & & & & & & 1.0 & & 2.8 & 2.3 & 1.2 & 1.9 & & \\
\hline Sugarbeet & 2.7 & 2.4 & & & 2.7 & 1.6 & 0.0 & 2.0 & 2.3 & 2.3 & 2.2 & 2.9 & 2.8 & 1.8 & & & 3.1 & & & 2.4 & 2.5 & 1.2 & 2.1 & 2.7 & 3.4 & & 1.7 & 2.8 \\
\hline Wheat & 1.6 & 2.1 & 1.4 & 1.0 & 1.4 & 1.5 & 1.2 & 1.2 & 1.8 & 2.0 & 1.3 & 2.1 & 1.8 & 1.2 & 1.9 & 1.5 & 1.7 & 2.0 & 2.1 & 1.6 & 1.2 & 0.7 & 1.5 & 1.1 & 1.8 & 1.9 & 1.4 & 2.0 \\
\hline Barley & 2.1 & 1.8 & 1.2 & 0.5 & 1.6 & 1.2 & 1.0 & 1.2 & 1.4 & 1.5 & 0.9 & 1.8 & 1.5 & 0.9 & 1.7 & 0.9 & 1.2 & 1.5 & 1.4 & 1.3 & 0.9 & 0.7 & 1.5 & 1.0 & 1.6 & 1.4 & 1.2 & 1.6 \\
\hline Maize & 1.4 & 1.0 & 1.5 & & 1.7 & 1.3 & & & 1.4 & 1.5 & 3.0 & 1.3 & 1.3 & 1.6 & & & 2.3 & 2.9 & & 1.5 & 1.3 & 2.1 & 1.8 & 2.7 & 1.2 & 1.2 & & \\
\hline Fiber sorghum & & & 3.2 & 2.2 & & & & & 2.1 & 1.7 & 2.4 & 3.1 & 2.9 & 1.8 & & & & & & & 2.7 & 2.7 & 3.7 & 2.3 & & & & \\
\hline Kenaf & & & 3.0 & 2.1 & & & & & 2.0 & 1.6 & 2.3 & 2.9 & 2.8 & 1.8 & & & & & & & 2.6 & 2.6 & 3.5 & 2.2 & & & & \\
\hline Miscanthus & & & 5.2 & 4.1 & 4.3 & 1.3 & & & 1.8 & 1.8 & 2.9 & 5.3 & 5.4 & 1.9 & 2.1 & 5.7 & 4.9 & 2.0 & 3.3 & 1.3 & 3.6 & 4.3 & 6.1 & 2.7 & 5.2 & 0.0 & 2.0 & 1.7 \\
\hline Switchgrass & & & 6.0 & 2.8 & 7.2 & 1.8 & & & 2.4 & 2.5 & 3.7 & 5.3 & 4.8 & 2.6 & 3.0 & 3.8 & 6.9 & 2.3 & 4.6 & 1.8 & 4.6 & 4.5 & 8.4 & 3.4 & 3.6 & 0.0 & 3.0 & 2.4 \\
\hline Cardoon & & & 1.4 & 1.9 & & & & & 1.2 & & 1.5 & 1.8 & 2.1 & 1.3 & & & & & & & 1.6 & 1.9 & 2.0 & 1.3 & & & & \\
\hline Willow & 0.9 & 0.8 & 1.0 & 0.8 & 1.1 & 0.7 & 1.0 & 0.9 & 0.8 & 0.8 & 0.8 & 1.0 & 1.0 & 0.7 & 0.9 & 1.0 & 1.1 & 0.8 & 1.0 & 0.7 & 0.9 & 0.9 & 1.1 & 0.8 & 1.0 & 1.0 & 0.8 & 0.9 \\
\hline Poplar & 0.9 & 0.8 & 1.0 & 0.8 & 1.1 & 0.7 & 1.0 & 0.9 & 0.8 & 0.8 & 0.8 & 1.0 & 1.0 & 0.7 & 0.9 & 1.0 & 1.1 & 0.8 & 1.0 & 0.7 & 0.9 & 0.9 & 1.1 & 0.8 & 1.0 & 1.0 & 0.8 & 0.9 \\
\hline
\end{tabular}




\section{References}

1. Elbersen, B.S.; Startisky, I.; Hangeveld, G.; Schelhass, M.-J.; Naeff, H. Atlas of EU Biomass Potentials: Spatially Detailed Overview of EU Biomass Potential Taking into Account Main Criteria Determining Biomass Availability from Different Sources; Biomass Futures, Alterra/IIASA: London, UK, 2012; Available online: https:/ec.europa.eu/energy/intelligent/projects/sites/iee-projects/files/projects/documents/ biomassfuturesatlas_of_technical_and_economic_biomass_potential_en.pdf (accessed on 21 January 2020).

2. EEA. EU Bioenergy Potential from a Resource Efficiency Perspective; EEA Report no.6/2013; EEA: Brussels, Belgium, 2013.

3. Fischer, G.; Prieler, S.; van Velthuizen, H.; Lensink, M.; Londo, M.; de Wit, M. Biofuel production potentials in Europe: Sustainable use of cultivated land and pas-tures. Part I: Land productivity potentials. Biomass Bioenergy 2010, 34, 159-172. [CrossRef]

4. Fischer, G.; Prieler, S.; van Velthuizen, H.; Lensink, M.; Berndes, G.; Faaij, A.; Londo, M.; de Wit, M. Biofuel production potentials in Europe: Sustainable use of cultivated land and pastures. Part II: Land use scenarios. Biomass Bioenergy 2010, 34, 173-187. [CrossRef]

5. GENTCHEV, G. DG Agriculture and Rural Development AGRI D.4. Revised EU Bioeconomy Strategy in the Context of CAP Post-2020. Available online: https://enrd.ec.europa.eu/sites/enrd/files/tg1_bioeconomy_ dgagri_gentchev.pdf (accessed on 22 January 2020).

6. James McEldowney and Patrick Kelly Members' Research Service PE 630.324. December 2018. CAP Strategic Plans. Available online: http://www.europarl.europa.eu/RegData/etudes/BRIE2018/630324/EPRS_BRI(2018) 630324_EN.pdf (accessed on 22 January 2020).

7. EU Science Hub. Renewable Energy—Recast to 2030 (RED II); EU Science Hub: Brussels, Belgium, 2018; Available online: https://ec.europa.eu/jrc/en/jec/renewable-energy-recast-2030-red-ii (accessed on 21 January 2020).

8. Ernst \& Young. Biofuels and Indirect Land Use Change. The Case for Mitigation. 2011. Available online: https: //www.iucn.org/sites/dev/files/content/documents/biofuels_and_indirect_land_use_change.pdf (accessed on 21 February 2020).

9. European Commission. Report from the Commission to the European Parliament, the Council, the European Economic and Social Committee and the Committee of the Regions on the Status of Production Expansion of Relevant Food and Feed Crops Worldwide; European Commission: Brussels, Belgium, 2019; Available online: https: //ec.europa.eu/transparency/regdoc/rep/1/2019/EN/COM-2019-142-F1-EN-MAIN-PART-1.PDF (accessed on 21 January 2020).

10. European Commission. Commission Delegated Regulation (EU). C(2019) 2055 Final Supplementing Directive (EU) 2018/2001 as Regards the Determination of High Indirect Land-Use Change-Risk Feedstock for which a Significant Expansion of the Production Area into Land with High Carbon Stock is Observed and the Certification of Low Indirect Landuse Change-Risk Biofuels, Bioliquids and Biomass Fuels; European Commission: Brussels, Belgium, 2019; Available online: https:/ec.europa.eu/transparency/regdoc/rep/3/2019/EN/C-2019-2055-F1-EN-ANNEX-1PART-1.PDF (accessed on 21 January 2020).

11. European Commission. Commission Delegated Regulation (EU) 2019/807 of 13 March 2019 Supplementing Directive (EU) 2018/2001 of the European Parliament and of the Council as Regards the Determination of High Indirect Land-Use Change-Risk Feedstock for which a Significant Expansion of the Production Area into Land with High Carbon Stock is Observed and the Certification of Low Indirect Land-Use Change-Risk Biofuels, Bioliquids and Biomass Fuels; European Commission: Brussels, Belgium, 2019; Available online: https://eur-lex.europa.eu/ legal-content/EN/TXT/PDF/?uri=CELEX:32019R0807 (accessed on 21 January 2020).

12. Allen, B.R.; Keegan, D.; Elbersen, B. Biomass and bioenergy in the wider land-use context of the European Union. Biofuels. Bioprod. Bioref. 2013, 7, 207-216. [CrossRef]

13. Fischer, G.; Hizsnyik, E.; Prieler, S.; Shah, M.; van Velthuizen, H. Biofuels and Food Security, Final Report to Sponsor: The OPEC Fund for International Development (OFID); IIASA: Laxenburg, Austria, 2009; Available online: http://pure.iiasa.ac.at/8969 (accessed on 21 January 2020).

14. Creutzig, F.; Ravindranath, N.H.; Berndes, G.; Bolwig, S.; Bright, R.; Cherubini, F.; Chum, H.; Corbera, E.; Delucchi, M.; Faaij, A.; et al. Bioenergy and climate change mitigation: An assessment. GCB Bioenergy 2015, 7, 916-944. [CrossRef] 
15. Khawaja, R. Janssen Sustainable Supply of Non-Food Biomass for a Resource Efficient Bioeconomy: A Review Paper on the State-of-the-Art WIP-Renewable Energies; Janssen: Munich, Germany, 2015; Available online: http://s2biom.alterra.wur.nl/doc/S2biom_review_state-of_the_art_Final.pdf (accessed on 22 January 2020).

16. Alexopoulou, E.; Christou, M.; Eleftheriadis, I. Role of $4 \mathrm{~F}$ cropping in determining future biomass potentials, including sustainability and policy related issue. Deliverable 3.2. Report of the Biomass Futures project. 2010. Available online: https://ec.europa.eu/energy/intelligent/projects/sites/iee-projects/files/projects/documents/ biomass_futures_future_biomass_potentials_role_of_4f_cropping_en.pdf (accessed on 21 January 2020).

17. Alexopoulou, E.; Papatheohari, Y.; Picco, D.; Monti, A.A.; Di Virgillio, N. Crop Management. Chapter 4 in "Kenaf: A Multi-Purpose Crop for Several Industrial Applications with New Insights from the Biokenaf Project"; Springer: Berlin, Germany, 2013.

18. Alexopoulou, E.; Cosentino, S.L.; Danalatos, N.; Picco, D.; Lips, S.; Van Den Berg, D.; Fernando, A.L.; Monti, A.; Tenorio, S.L.; Kipriotis, E.; et al. New insights from the BIOKENAF Project. Chapter 8 in "Kenaf: A Multi-Purpose Crop for Several Industrial Applications with New Insights from the Biokenaf Project"; Springer: Berlin, Germany, 2013.

19. Alexopoulou, E.; Zanetti, F.; Scordia, D.; Zegada-Lizarazu, W.; Christou, M.; Testa, G.; Cosentino, S.L.; Monti, A. Long-term yields of switchgrass, giant reed and miscanthus in the Mediterranean basin. Bioenergy Res. 2015, 8, 1492-1499. [CrossRef]

20. Alexopoulou, E.; Papatheohari, Y.; Siqi, U.; Scordia, D.; Testa, G. How kenaf (Hibiscus cannabinus L.) can achieve high yields in Europe and China. Ind. Crops Prod. 2015, 68, 131-140. [CrossRef]

21. Alexopoulou, E.; Papatheohari, Y.; Zanetti, F.; Tsiotas, K.; Papamichael, I.; Christou, M.; Namatov, I. Comparative studies on several castor (Ricinus communis L.) hybrids: Growth, yields, seed oil and biomass characterization. Ind. Crops Prod. 2015, 75, 8-13. [CrossRef]

22. Bassam, E. Handbook of Bioenergy Crops: A Complete Reference to Species, Development and Applications; Earthscan: London, UK, 2010.

23. Biomass Futures. Final Technical Report. 2012. Available online: www.biomassfutures.eu (accessed on 22 January 2020).

24. Cosentino, S.L.; Patanè, C.; Sanzone, E.; Copani, V.; Foti, S. Effects of soil water content and nitrogen supply on the productivity of Miscanthus x giganteus Greef et Deu. in a Mediterranean environment. Ind. Crops Prod. 2007, 25, 75-88. [CrossRef]

25. Fazio, S.; Barbanti, L. Energy and economic assessments of bio-energy systems based on annual and perennial crops for temperate and tropical areas. Renew. Energy 2014, 69, 233-241. [CrossRef]

26. Fernandez, J.; Curt, M.D.; Aguado, P.L. Industrial applications of Cynara cardunculus L. for energy and other uses. Ind. Crops Prod. 2006, 24, 222-229. [CrossRef]

27. Guidi, W.; Piccioni, E.; Bonari, E. Evapotranspiration and crop coefficient of poplar and willow short-rotation coppice used as vegetation filter. Bioresour. Technol. 2008, 99, 4832-4840. [CrossRef] [PubMed]

28. Lewandowski, I.; Clifton-Brown, J.; Murphy-Bokern, D. Perennial Biomass Crops for a Resource-Constrained World, Biomass 2015 Summary, (Stuttgart-Hohenheim, Germany 7-10 September); Wiley: Hoboken, NJ, USA, 2015; pp. 1-31. Available online: www.biomass2015.eu (accessed on 21 January 2020).

29. Kahle, P.; Beuch, S.; Boelcke, B.; Leinweber, P.; Schulten, H.R. Cropping of Miscanthus in Central Europe: Biomass production and influence on nutrients and soil organic matter. Eur. J. Agron. 2001, 15, 171-184. [CrossRef]

30. Kandel, T.P.; Hastings, A.; Jorgensen, U.; Olesen, J.E. Simulation of biomass yield of regular and chilling tolerant Miscanthus cultivars and reed canary grass in different climates of Europe. Ind. Crops Prod. 2016, 86, 329-333. [CrossRef]

31. Bos, H.; Meesters, K.; Conijn, J.G.; Corré, W.; Patel, M. Sustainability Aspects of Biobased Applications, Comparison of Different Crops and Products from the Sugar Platform; Report 1166; Food and Biobased Research: Wageningen, NL, USA, 2010.

32. FAO. Global Trends in Production and Consumption of Carbohydrate Foods. Available online: http: //www.fao.org/docrep/w8079e/w8079e0g.htm (accessed on 22 January 2020).

33. Eurostat. Available online: http://www.agri-info.eu/english/t_wages.php (accessed on 22 January 2020). 
34. Farm Accountancy Data Network (FADN). 2017. Available online: http://ec.europa.eu/agriculture/rica/ (accessed on 31 March 2017).

35. Soldatos, P.G. Large-scale biomass cultivation for energy in the EU. Evaluation of long-term impact on farm income, employment and the environment. In Proceedings of the RE Development EC Conference and the Contractor's Meeting, Brussels, Belgium, June 1996; pp. 315-319.

36. Panoutsou, C. Socio-economic impacts of energy crops for heat generation in Northern Greece. Energy Policy 2007, 35, 6046-6059. [CrossRef]

37. Gittinger, J.P. Economic Analysis of Agricultural Projects, EDI Series in Economic Development; World Bank: Washington, DA, USA, 1995.

38. Wildegger, B.; Zimmer, Y. Rapeseed, Sunflower or Soybean-Which Oilseed Crop has the Highest on-Farm Competitiveness? 2015. Available online: http://www.agribenchmark.org/agri-benchmark/news-and-results/ einzelansicht/artikel//rapeseed-su.html (accessed on 22 January 2020).

39. Mollman, T. The Costs of Growing Wheat around the World, Alook at Agri-Benchmark Typical Farms. Available online: https://www.agritechnica.com/fileadmin/downloads/2015/Programm/Forum_3/F3-13-111200_Moellmann.pdf (accessed on 22 January 2020).

40. Vasilakoglou, I.; Dhima, K. Potential of two cardoon varieties to produce biomass and oil under reduced irrigation and weed control inputs. Biomass Bioenergy 2014, 63, 177-186. [CrossRef]

41. Tate, G.; Mbzibain, A.; Ali, S. A comparison of the drivers influencing farmers' adoption of enterprises associated with renewable energy. Energy Policy 2012, 49, 400-409. [CrossRef]

42. Sherrington, C.; Moran, D. Modelling farmer uptake of perennial energy crops in the UK. Energy Policy 2010, 38, 3567-3578. [CrossRef]

43. Wang, S.; Wang, S.; Hastings, A.; Pogson, M.; Smith, P. Economic and greenhouse gas costs of miscanthus supply chains in the United Kingdom. GCB Bioenergy 2012, 4, 358-363. [CrossRef]

44. Bauen, A.W.; Dunnett, A.J.; Richter, G.M.; Dailey, A.G.; Aylott, M.; Casella, E.; Taylor, G. Modelling supply and demand of bioenergy from short rotation coppice and miscanthus in the UK. Bioresour. Technol. 2010, 101, 8132-8143. [CrossRef]

45. Clancy, D.; Breen, J.; Moran, D.; Thorne, F.; Wallace, M. Examining the socio-economic factors affecting willingness to adopt bioenergy crops. J. Int. Farm Manag. 2011, 4, 5.

46. Diamantidis, N.D.; Koukios, E.G. Agricultural crops and residues as feedstocks for non-food products in western Europe. Ind. Crops Prod. 2000, 11, 97-106. [CrossRef]

47. Huang, H.X.; Khanna, M.; Booth, E.; Halford, N.; Shield, I.; Taylor, G. The breakeven costs of alternative feedstocks for cellulosic biofuels. ASP Appl. Biol. 2011, 112, 153-162.

48. James, L.K.; Swinton, S.M.; Thelen, K.D. Profitability analysis of cellulosic energy crops compared with corn. Agron. J. 2010, 102, 675-687. [CrossRef]

49. Lychnaras, V.; Schneider, U. A Multi-farm economic analysis of perennial energy crops in central Greece, taking into account the CAP reform. Biomass Bioenergy 2011, 35, 700-715. [CrossRef]

50. Laporte, A.V.; de Weersink, A.J.; McKenney, D.W. A spatial model of climate change effects on yields and breakeven prices of switchgrass and miscanthus in Ontario, Canada. GCB Bioenergy 2014, 6, 390-400. [CrossRef]

51. Hauk, S.; Knoke, T.; Wittkopf, S. Economic evaluation of short rotation coppice systems for energy from biomass-A review. Renew. Sustain. Energy Rev. 2014, 29, 435-448. [CrossRef]

52. Bocquého, G.; Jacquet, F. The adoption of switchgrass and miscanthus by farmers: Impact of liquidity constraints and risk preferences. Energy Policy 2010, 38, 2598-2607. [CrossRef]

53. Jain, A.K.; Khanna, M.; Erickson, M.; Huang, H. An integrated biogeochemical and economic analysis of bioenergy crops in the midwestern United States. GCB Bioenergy 2010, 2, 217-234. [CrossRef]

54. Alexander, P.; Moran, D.; Rounsevell, M.; Smith, P. Modelling the perennial energy crop market: The role of spatial diffusion. JR Soc. Interface 2013, 10, 20130656. [CrossRef]

55. Panoutsou, C. The Role of Sustainable Biomass in the Heat Market Sector for EU27; Wiley Interdisciplinary Reviews Energy and Environment: Hoboken, NJ, USA, 2016; Volume 5, pp. 430-450. ISSN 2041-8396. 
56. Mantziaris, S.; Iliopoulos, C.; Theodorakopoulou, I.; Petropoulou, E. Perennial energy crops vs. Durum wheat in low input lands: Economic analysis of a Greek case study. Renew. Sustain. Energy Rev. 2017, 80, 789-800. [CrossRef]

57. Styles, D.; Thorne, F.; Jones, M.B. Energy crops in Ireland: An economic comparison of willow and Miscanthus production with conventional farming systems. Biomass Bioenergy 2008, 32, 407-421. [CrossRef]

58. Glithero, N.J.; Wilson, P.; Ramsden, S.J. Prospects for arable farm uptake of short rotation coppice willow and miscanthus in England. Appl. Energy 2013, 107, 209-218. [CrossRef] [PubMed]

(C) 2020 by the authors. Licensee MDPI, Basel, Switzerland. This article is an open access article distributed under the terms and conditions of the Creative Commons Attribution (CC BY) license (http://creativecommons.org/licenses/by/4.0/). 